\title{
PRIMARY SCHOOL TEACHERS' OPINIONS TOWARDS MUSICALLY GIFTED STUDENTS
}

\author{
Vesna Svalina \\ Josip Juraj Stroyymayer University of Osijek, Croatia \\ E-mail: vesna.svalina@gmail.com \\ Blaženka Bačlija Sušić, Goran Lapat \\ University of Zagreb, Croatia \\ E-mail: blazenkabs@gmail.com, goran.lapat@ufzg.hr
}

\begin{abstract}
Primary school teachers have an important role in the early identification and further development of a child's musical giftedness. The research was aimed to examine the opinions of primary school classroom teachers $(N=1130)$ employed in Croatian primary schools regarding conceptualization of musical giftedness and its impact on identification of musically gifted students. Furthermore, their opinions about the support of parents, professional team and collective as well as competencies for recognizing and further development of the child's musical giftedness were investigated. Although most respondents assess their competencies in identifying musical giftedness, most of the surveyed teachers, especially younger ones, are willing to be additionally trained in this area. They stated that the existing curriculum should be expanded and enriched and stressed the need for more support from the expert assistants (psychologists and pedagogues). In addition to the teachers' age, their title (teacher, teacher mentor and teacher advisor) also proved to be a significant factor in the identification and development of a child's musical giftedness. Findings of research have implications for theory and practice of primary school teacher's music education and education for work with gifted children both during their higher education and lifelong learning.
\end{abstract}

Keywords: musical giftedness, musically gifted students, primary school teachers, Republic of Croatia

\section{Introduction}

The problem of musical giftedness in individual societies largely depends on the musical culture of the society, which further influences the system of music education. The cultural environment of an individual society, its musical creativity and musical education affect the development of children's musical abilities, thus contributing to the creation of differences in different cultures (Sukop et al., 2016). With regard to the educational vertical, educators and teachers in the early grades of primary school, along with parents and guardians, are the first to meet musically gifted children and therefore have an important role in its identification.

The conceptualization of the musical giftedness is primarily related to different approaches to musical activities within music education. Emphasizing the importance of active participation in the process of music education, some researchers observe children as natural / spontaneous creators of music (Elliott, 2009), initiators of musical activities (Burnard \& Murphy, 2017), creators of musical ideas (Wiggins, 2007) and the musical innovators (Marsh, 2008). A quality way of teaching music also implies the competencies of teachers to conduct musical activities that also include competencies for the identification of musically gifted children. Accordingly, teachers are expected to have a dual role - to be both a student and a researcher in their class (Montgomery, 2015) in order to find the best way of conducting musical activities with children and to develop their own theory. 
Vesna SVALINA, Blaženka BAČLIJA SUŠIĆ, Goran LAPAT. Primary school teachers' opinions towards musically gifted students

PROBLEMS

OF EDUCATION

IN THE $21^{\text {st }}$ CENTURY Vol. 79 , No. 1, 2021

134

Accordingly, teachers are expected to have a dual role - both a student and a researcher in his class (Montgomery, 2015) to find the best way of conducting musical activities with children and to develop his own theory. This requires constant professional development of teachers that will contribute to the improvement of his theoretical knowledge, and therefore a better understanding of the very concept of child music giftedness, and its identification in educational practice as well.

It is important that the teacher's assessment of musically gifted students is not based solely on common indicators of musical giftedness and school success. With referral of children to additional music education as extracurricular activities, it is important to involve children in special art programs within schools. Attention should also be paid to those children who may not have good grades, do not write homework, do not participate actively in class, or do not have enough self-confidence (Schroth \& Helfer, 2020).

Although there is relatively scarce amount of recent research in this area focused on the issue of musical giftedness of lower primary school students (Bačlija Sušić \& Svalina, 2018; Sukop et al., 2016; Schroth \& Helfer, 2020; Zalar \& Sicherl-Kafol, 2015), emphasizing the importance and possibilities of improving work with musically gifted children in the lower grades of elementary school, Lelea (2014) considers that "identification and encouragement of musical giftedness is one of the primary goals of modern education that presents a challenge for research" (Lelea, 2014, p. 61). The positive culture of the school is also an important factor in identifying musically gifted students as it supports the professional cooperation of teachers with other staff members (Antinluoma, Ilomäki et al., 2018), therefore in accordance with this, the cooperation of teachers with music teachers and members of the professional team is also expected. Given that quality music education primarily depends on quality teaching and quality collaboration and support, it is important to provide the necessary music and professional development for primary school teachers (Clarke, 2007).

In accordance with the educational system of the Republic of Croatia, early identification of musical giftedness is expected from primary school teachers, since it is only in the fourth grade of primary school that music teachers take over music lessons from teachers. Therefore, it is especially important for the teacher to be competent in recognizing the musical giftedness of the student in order to timely refer her/ him for further music education within specialized music schools.

\section{About the Terms 'Giftedness' and 'Talent'}

The terms 'giftedness' and 'talent' are interpreted in different ways in available literature. The use of these terms is often ambiguous and inconsistent, and there is no generally accepted definition that relates to them (Davis et al., 2014). Failure to understand the construct of giftedness itself is one of the fundamental factors leading to a discussion of this problem (Erwin \& Worrell, 2012). The results of new research have brought about a change in the definition of the concept or idea of giftedness (Tannenbaum, 2000). Both culture and politics have contributed to the change in the understanding of the notion of giftedness (Moon \& Rosselli, 2000), so from the narrow, intellectually based conceptions of giftedness, broader conceptions have emerged, that recognize talents in specific domains (McClain \& Pfeiffer, 2012). Accordingly, some authors describe giftedness as the potential for the remarkable development of certain abilities as well as for success, which is at the top of the continuum of talent expression (George, 2004).

Through the WICS Model of Giftedness (WICS - Wisdom, Intelligence, Creativity, Synthesized), Sternberg (2003) contributed to the systematization and development of knowledge about the metacognitive functioning of gifted people. Observing giftedness as a synthesis of wisdom, intelligence, and creativity, Sternberg ultimately pointed out and emphasized the role of culture in the conceptualization of giftedness (Sternberg, 2007, 2012). 
Renzulli $(1978,1986,2002)$ focused on the behaviour of the gifted and, within his threering model of giftedness, views the behaviour of the gifted from three aspects, more precisely as three groups of human traits (above-average ability, high level of commitment and high level of creativity). It is believed that creative performance, which is also called creative productivity, requires above-average abilities and creativity and dedication to the task.

Based on existing theories, Gagné $(1985,1999,2000,2004)$ developed his complex theory of giftedness Differentiated Model of Giftedness and Talent (DMGT) (Gagné, 2000, 2004), according to which he points out the differences in the notion of giftedness related to natural abilities and talent related to learned abilities. In doing so, he pointed out that environmental and intrapersonal catalysts (e.g., someone's miles, motivation) and factor of chance contribute to or hinder talent development through a long-term process. In line with the above, both the notion of giftedness and the notion of talent are used in this paper, depending on the specific problems that the authors were considering.

Regardless of the definition of this term, it is extremely important for the child's overall development to adapt and to be provided with quality early experiences and development in accordance with individual needs. Gifted students, those with highly developed abilities in a certain field, need to be approached in the same way as students with lower achievements, because only then will they be able to use their full potential. Accordingly, some authors emphasized the special needs of gifted children, stressing that without proper education, their potentials and achievements at more advanced levels of education will not be realized (White et al., 2003; Hargrove, 2009).

\section{Musical Giftedness}

Historically, musical giftedness and talent has been defined in various ways since the very beginnings of the development of this field within the psychology of music. Unlike Billroth (2017), who described musical talent through characteristics inherent to an individual's behaviour (interests and musical memory) and specific auditory abilities, Seashore (1919), in his work The Psychology of Musical Talent, discusses musical talent as a hierarchy of characteristics derived from innate sensory capacities manifested from early childhood. An instrument for measuring musical talent called the Seashore Measures of Musical Talent (1919) emphasized that a reliable measurement of a child's musical abilities can be carried out at the age of ten. Beyond that age, the child's musical potential stabilizes, after which further training can only improve the existing musical potential but cannot extend it.

One of the clues and indicative elements confirming the emergence of musical giftedness earlier than giftedness in other domains (at the age of 1 or 2) (Winner \& Martino, 2000) is children's fascination by musical sounds. Very young children are often enthralled by musical sounds which is evident from their reactions to music.

Gordon (1986) has believed that the child's musical potential stabilizes before the age of nine, in accordance with the child's audition ability (ability to mentally represent the aural images of music), immediate impressions and intuitive reactions to music:

Because the music aptitude of children younger than nine years of age is a product of both innate potential and early environmental influences, music aptitude that is measured during the first few years of life is called developmental music aptitude, and because environmental influences no longer have any effect on children's music aptitudes after they reach approximately nine years of age, music aptitude measured after that time is called stabilized music aptitude. (Gordon, 2003, p. 15) 
Vesna SVALINA, Blaženka BAČLIJA SUŠIĆ, Goran LAPAT. Primary school teachers' opinions towards musically gifted students

PROBLEMS

OF EDUCATION

IN THE $21^{\text {st }}$ CENTURY Vol. 79 , No. 1,2021

136

Musical intelligence is one of the intelligence types listed by Howard Gardner in his Theory of Multiple Intelligences (Gardner, 1983). This type of intelligence develops at the earliest age (infants recognize sounds and music before they are able to recognize even the basic properties of speech) and it was found that the sensory components of musical intelligence reflect the components of the child's musical potential (aptitude) and thus contribute to better understanding and recognition.

This theory has a dual role. On the one hand, it provides a useful framework for understanding a person's core competencies, and on the other, it contributes to the understanding of their unique competencies and abilities. This way, it provides better insight into the child's abilities and potentials, and it is precisely the recognition of abilities and giftedness in all areas and their further development that is the basic task of the educational system. A child's musical talent can be spotted in much the same way.

\section{Identification of Musical Giftedness}

In line with the above findings, early identification of a child's musical giftedness is paramount. There are a wide range of individual differences in gifted individuals that manifest in various ways. Accordingly, some researchers believe that the identification of a musically gifted child can pose a problem for educators and teachers because musically gifted children are not a homogeneous group, and therefore the issue of giftedness is quite complex (Jeremić \& Milenović, 2017). In order to strengthen their competencies and become more proficient in recognizing musical giftedness in children, educators and teachers are expected to undergo lifelong professional development in the field of music. It is considered less wrong to include a non-gifted child in the group of gifted children, than vice versa, to declare a gifted child ungifted and thus prevent them from further developing their giftedness (Cvetković-Lay \& Sekulić Majurec, 2008).

In making this decision, it is important to become familiar with the different methods of identifying giftedness, to make the process as successful as possible. In educational practice, several methods and techniques are used to discover and identify gifted students through assessment procedures, tests and interview techniques. Giftedness is often identified with achievement, so excellent student achievement is a fundamental criterion in identifying giftedness (Gordon, 1995, according to Haroutounian, 2002). The same researchers pointed out that this is also the case in music education, given that more attention is often focused on musical achievements than on the musical potential of an individual (Gordon, 1995, according to Haroutounian, 2002). This was confirmed by research on the identification of musically gifted students by teachers, that indicated that school performance is a key factor in assessing students' musical giftedness (Hany, 1991; Rost \& Hanses, 1997). For example, performance at a school event is a basic indicator of a musically gifted student, but studies show that about 50 per cent of students (of which 20 per cent with the highest musical aptitude) have never participated in musical performances at school and therefore have never demonstrated any musical achievements because they had no opportunity to do so. The underlying reason for this is the fact that teachers failed to recognize their musical potential (Gordon, 1995, according to Haroutounian, 2002). Therefore, the same author believes that, in identifying musical giftedness, it is important to take into account the musical potential and musical achievements of students.

Today, multiple assessment methods are increasingly being used, whereby the process of identifying the musical potential and giftedness of children represents an integration of different assessment methods (observation, assessment of musical giftedness according to the performance and listening to music, etc.) with the use of tests. For example, less formal methods and assessment procedures are being used, including case studies and the use of informal statements and opinions of interested observers in the context of the child's development 
(Cvetković-Lay, 2006). The basic purpose is to ensure more challenging individualized tasks for students who have the potential to develop their musical giftedness beyond the level envisaged by the curriculum.

The identification of musical giftedness should primarily be considered an incentive for the enrichment of the existing curriculum and not for its replacement because it is important for music education to be an integral part of every child's education. It is therefore necessary to provide a possibility of individualized development for students with greater musical potential, beyond what is provided by the curriculum. Therefore, a clear understanding of the criteria of potential musical giftedness stands out as a crucial and effective procedure for identifying musically gifted students.

In line with the above, educators and teachers are expected to continuously improve upon and develop their competencies for the timely identification of gifted children. According to Bogunović (2008), in addition to parents, the most influential people in the early period of a child's musical development are teachers and educators. Given that they "contribute to the development of musical abilities, but also to the musical taste and values, they are seen as role models and key promoters of motivational development - for better or worse" (Bogunović, 2008, p. 207). Furthermore, it is pointed out that "the role of educator and teacher consists of their competencies and skills to instruct children in mastering the cognitive, emotional and psychomotor processes of knowledge acquisition in order to develop giftedness" (Bogunović, 2008, p. 209). Teachers and educators need to be continuously encouraged to seek professional development, to acquire and improve their competencies for the timely recognition of gifted children (Milenović \& Lučin, 2011). As one of the ways of developing teacher competencies for recognizing musical giftedness, Haroutounian (2002) proposed cooperation with music teachers or special training led by them.

\section{Croatian Context}

According to the Ministry of Science and Education (MSE) that is responsible for the education system in the Republic of Croatia primary education begins with enrolment in the first grade of primary school. It is compulsory for all children in duration of eight years and contains of curricular and extra-curricular programs. In primary education, students acquire knowledge and skills for continuing their education in secondary schools that are not compulsory.

Music education in Croatia is compulsory in the primary school curriculum and implemented in the framework of the school subject Music Culture. As stated in the Curriculum of Music Culture and Music Arts for Primary Schools and Grammar Schools $(2019$, p. 4), the fundamental goals of music teaching in compulsory education are "to enable the socio-emotional development of all students, including gifted students and students with disabilities; to encourage the development of musical abilities of all students in line with the individual's abilities; to encourage students to actively engage in music and participate in the community's cultural life; to familiarize students with musical art through quality and representative performances of music of different origin and different styles and types; to encourage the development of musical taste and critical thinking; to foster understanding of the interdisciplinary characteristics and possibilities of music; to raise awareness of the values of regional, national and European cultural heritage in the context of world culture; to develop cultural understanding and intercultural competence by building relationships towards their own and an open approach to other musical cultures."

According to the Croatian National Curriculum Framework (2011) and the existing Primary School Curriculum (2006), music is taught in all eight grades of Croatian primary schools. The annual curricular fund for music teaching is 35 hours, i.e., one lesson per week. In the first three grades of primary school, music lessons are taught by classroom teachers and 
Vesna SVALINA, Blaženka BAČLIJA SUŠIĆ, Goran LAPAT. Primary school teachers' opinions towards musically gifted students

PROBLEMS

OF EDUCATION

IN THE $21^{\text {st }}$ CENTURY Vol. 79 , No. 1,202

138

from the fourth-grade music lessons can be taught by classroom teachers or specialized music teachers. From the fifth to the eighth grade, music lessons are regularly taught by specialized music teachers.

In the education system of the Republic of Croatia, parallel primary education in the form of primary art education is also possible. According to the Art Education Act (2011), funds for financing public needs in art education are provided from the state budget, the local government budget and parental participation. Primary music education conducted according to the primary art curriculum, lasts six years, while primary dance education lasts four years (Svalina, 2015). Music schools are most often separate from general education schools and enrol "children whom parents consider to be musically gifted, i.e., children who have passed the exam of basic musical abilities" (Svalina \& Matijević, 2011, 437).

In music schools, students are much more intensely involved in music than is the case in general education schools. In addition to mastering the skill of playing a musical instrument, in music schools students develop their rhythmic and intonation skills in solfeggio lessons and have the opportunity to participate in music groups by singing in choirs or playing in orchestras (Svalina, 2015, p. 87).

According to the Ordinance on the Promotion of Teachers (2005) prescribed by The Ministry of Science and Education (MSE), during their careers, teachers can advance in their profession in teacher mentor and teacher advisor. The first title that a teacher can advance to is the title of mentor after five years of teaching during which they must have professional development and met the requirements of excellence in the adoption of learning outcomes with a minimum of seven points in extracurricular activities. After five years as a mentor, a teacher can become an advisor. This means that a teacher can become an advisor after a minimum of eleven years of service with professional development and with a minimum of 15 points in extracurricular activities (Ordinance on the Promotion of Teachers, 2005).

\section{Research Aim and Research Questions}

Survey was conducted with an aim to examine the opinions of primary school teachers on the development of musical giftedness in primary school students. The research questions were:

1. How do Croatian teachers conceptualize musical giftedness?

2. How does this conception affect the identification and provisions for musically gifted students?

3. How satisfied are teachers with their competencies for recognizing and further developing the musical giftedness of students in the first four grades of primary school?

4. What are the conditions for encouraging and developing musical knowledge and skills in musically gifted students, with regard to the support of their parents, professional team and collective?

\section{Research Methodology}

\section{General Background}

Given that teachers play an important role in the early identification and development of a child's musical giftedness, a clear understanding of the criteria of potential musical giftedness is needed for its identification and further individualized development. Conducting research 
related to the identification of musical giftedness of students by their primary school teachers represents a special contribution to the issue of giftedness development. Such studies contribute to better teacher education during their college studies, as well as to teachers who work in practice. They also contribute to the development of programs that further contribute to the identification of gifted students in all segments of education and better education of musically gifted students.

It is the wish of Croatian researchers to establish cooperation in this field with researchers from other countries in order to exchange experiences, knowledge and good practice that will help achieve the overall goal of improving the situation in the context of artistic work with gifted students. Therefore, a bilateral project was launched involving scientists from several Croatian and Slovenian universities. It is a project called "Giftedness in the artistic field - analysis of the situation among primary school students in terms of artistic and musical giftedness." The project was implemented as part of bilateral cooperation between Croatia and Slovenia from 2017 to 2019 and was funded by the Ministries of Education of the two countries. In this study, we present some of the results obtained within this bilateral project. In order the teachers have more clear understanding of the criteria for identification of potential musical giftedness, the research in primary schools in Croatia was conducted from May 2019 to July 2019. This study employed the mixed method design which is the combination of qualitative and quantitative methodological approaches. A questionnaire was developed for the purposes of this research while descriptive and inferential statistics were used for data analysis.

\section{Sample Selection}

In the research was used a random sample (Cohen et al., 2000) comprised of 1,130 primary school classroom teachers (1,093 female teachers $-96.2 \%$ and 37 male teachers $-3.3 \%)$. These were Croatian teachers, employed in primary schools in 21 counties. Most teachers were from the City of Zagreb (159, 14.1\%), Zagreb County (91, 8.1\%), Primorje-Gorski Kotar County (85, 7.5\%), Krapina-Zagorje County (78, 6.9\%), and Osijek-Baranja County (75 6.6\%). Each of the remaining 16 counties was represented by less than $6 \%$. The number of teachers from urban $(552,48.6 \%)$ and rural areas $(573,50.4 \%)$ was equal. The average years spent teaching for the teachers from the sample was 21. Of the total number of teachers, 141 teachers had the title of teacher mentor $(12.4 \%)$, and 66 teachers $(5.8 \%)$ had the title of teacher advisor.

Most teachers were aged 51 and over $(411,36.2 \%)$, while the number of teachers in the age group of $41-50$ years $(345,30.4 \%)$ and $31-40$ years $(292,25.7 \%)$ was slightly lower. Fewest participants belonged to the group of up to 30 years, i.e., youngest teachers $(84,7.4 \%)$. The sample was organised by dividing the teacher population into four groups, whereby the first group consisted of teachers aged 30 or under (A), the second group consisted of teachers aged 31 to 40 (B), the third group consisted of teachers aged 41 to 50 (C), and the fourth group consisted of teachers aged 51 and over (D). The second criterion were their titles: teachers (A), teacher mentors (B), and teacher advisors (C). Since we decided to use a random sample, the conclusions cannot be generalized to the entire population of Croatian teachers. Nevertheless, we could draw some conclusions from the research.

\section{Instrument and Procedures}

We used the surveying process during the research. The questionnaire was developed for the purposes of this research by the project team members. The survey was anonymous. The first part of the questionnaire (6 questions) included questions concerning the sociodemographic characteristics of the research participants: gender, age, length of service, their title, their school county and school environment (urban or rural). The second part included

$\mid$\begin{tabular}{l} 
PROBLEMS \\
OF EDUCATION \\
IN THE 21 1 st CENTURY \\
Vol. 79, No. 1, 2021 \\
\hline 139
\end{tabular} 
Vesna SVALINA, Blaženka BAČLIJA SUŠIĆ, Goran LAPAT. Primary school teachers' opinions towards musically gifted students

PROBLEMS

OF EDUCATION

IN THE $21^{\text {st }}$ CENTURY

Vol. 79 , No. 1,202

140

questions concerning the number of musically gifted students in the class and how to recognize musically gifted students, while the third part included a series of statements related to the assessment of the importance of recognizing musically gifted students, the need to ensure the conditions necessary to encourage and develop musical giftedness in students and the (self) assessment of competencies for recognizing and further developing the musical giftedness of primary school students. The survey includes open questions, multiple choice questions, questions on numerical values, and 5-point Likert scale ( 1 = strongly disagree, $2=$ disagree, $=$ neither agree nor disagree, $4=$ agree, $5=$ completely agree). The reliability of the instrument is satisfactory (Cronbach's Alpha $=.79$ ).

Primary school classroom teachers were invited to participate in the research via the principals of primary schools in which they are employed. An official letter was sent to all principals of Croatian primary schools asking them to invite all classroom teachers to participate in research.

\section{Data Analysis}

Quantitative and qualitative analyses were used for data processing. For the qualitative analysis, it was necessary to encode the data, which enabled certain answers from the survey questionnaire to be translated into categories and to be converted into a certain result (Cohen et al., 2000), while some phenomena, i.e., their frequency was expressed quantitatively. Based on the results obtained, the basic descriptive parameters: arithmetic mean $(M)$, standard deviation (SD) and the percentage of answers obtained, were calculated. Also, certain procedures of inferential statistics were used. The statistics program SPSS V26 was used for the processing of statistical data. The normality of distribution of individual variables was tested by the Kolmogorov-Smirnov test and was found that the distribution was not normal. Therefore, data analysis was continued by non-parametric methods. The non-parametric Kruskal-Wallis test (H) (Opić, 2010; Petz, 2007; Suzić, 2007), with a statistical significance at the level of .05, was used to compare the differences in the answers with regard to the age and title of the teacher.

\section{Research Results}

The teachers stated that in the school year 2018/2019, there were between 4 and 28 students per class. The largest number of teachers stated that, during that particular school year, they identified musical giftedness in one $(196,18.6 \%)$, two $(230,21.9 \%)$ or three students $(135$, $12.8 \%)$. Some teachers did not recognize any gifted students in their class $(140,13.3 \%)$. Table 1 shows the most common teacher responses concerning the number of gifted students. 
Table 1

Number of Musically Gifted Students Per Class in the 2018/2019 School Year

\begin{tabular}{cc}
\hline Number of musically gifted students per class & Frequency \\
\hline Ten & 35 \\
Nine & 6 \\
Eight & 21 \\
Seven & 22 \\
Six & 44 \\
Five & 96 \\
Four & 87 \\
Three & 135 \\
Two & 230 \\
One & 196 \\
None & 140 \\
\hline
\end{tabular}

When it comes to the importance of specific procedures related to the recognition of musical giftedness in primary school students, teachers believed that the most important thing is to encourage a musically gifted child to attend additional curricular and extracurricular activities $(M=4.50 ; S D=0.60)$ and to detect the child's musical giftedness as early as possible $(M=4.37 ; S D=0.60)$. Three-quarters of teachers believe that it is very important to monitor and document the indicators of students' musical giftedness in class $(M=3.87 ; S D=0.72)$, and two-thirds believe that it is important to use measurement scales to test students' abilities in these areas $(M=3.80 ; S D=0.81)$ and inform expert assistants (psychologists and pedagogues) after identifying musically gifted students $(M=3.72 ; S D=0.91)$ (Figure 1).

\section{Figure 1}

Importance of Procedures for Recognizing the Musical Giftedness of Primary School Students (Average values of teacher opinions (M))

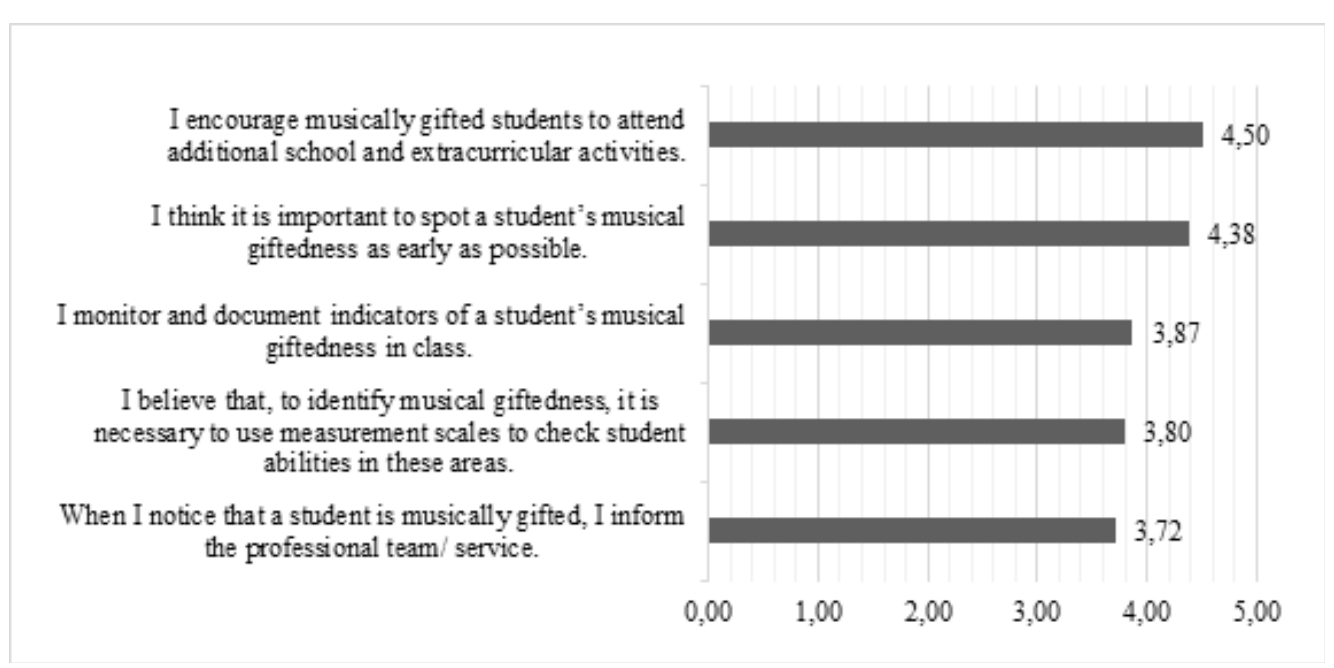


Vesna SVALINA, Blaženka BAČLIJA SUŠIĆ, Goran LAPAT. Primary school teachers' opinions towards musically gifted students

PROBLEMS

OF EDUCATION

IN THE $21^{\text {st }}$ CENTURY

Vol. 79, No. 1, 2021

Teachers were divided into four age-groups: teachers aged 30 or under (A), teachers aged 31 to 40 (B), teachers aged 41 to 50 (C), and teachers aged 51 or over (D). Their opinions on the importance of procedures related to the recognition of musical giftedness in students in the first four grades of primary school were then compared. The results showed that the youngest group of teachers emphasizes the importance of most procedures related to the identification of musically gifted students more than teachers from other age groups. Only when asked about the importance of encouraging musically gifted students to attend additional curricular and extracurricular activities were the results higher in older groups of teachers (aged 41-50 and 51 and over). The greatest standard deviation was found in the answers concerning the importance of informing the team of expert assistants (psychologists and pedagogues) on the identification of a musically gifted student $(S D=0.91)$, and the lowest value of dispersion was found in the answers concerning the importance of encouraging musically gifted students to attend additional curricular and extracurricular activities $(S D=0.60)$ and the importance of early identification of the student's musical giftedness $(S D=0.60)$. The Kruskal-Wallis $H$-test was used to check whether the differences in teacher responses in relation to their age were statistically significant. No significant differences were found at the .05 level (Table 2).

Table 2

Teachers' Opinions on the Importance of Procedures for Identifying Musical Giftedness in Relation to Their Age

\begin{tabular}{|c|c|c|c|c|c|c|}
\hline Statement & Teacher's age & $N$ & $M$ & $S D$ & $H$ & $p$ \\
\hline \multirow{4}{*}{$\begin{array}{l}\text { I encourage musically gifted students } \\
\text { to attend additional school and } \\
\text { extracurricular activities }\end{array}$} & 30 and under & 65 & 4.43 & 0.61 & \multirow{4}{*}{3.683} & \multirow{4}{*}{.298} \\
\hline & $31-40$ & 240 & 4.46 & 0.59 & & \\
\hline & $41-50$ & 284 & 4.51 & 0.62 & & \\
\hline & 51 and over & 313 & 4.53 & 0.59 & & \\
\hline \multirow{4}{*}{$\begin{array}{l}\text { I think it is important to spot a student's } \\
\text { musical giftedness as early as possible }\end{array}$} & 30 and under & 68 & 4.50 & 0.56 & \multirow{4}{*}{5.205} & \multirow{4}{*}{.157} \\
\hline & $31-40$ & 255 & 4.32 & 0.61 & & \\
\hline & $41-50$ & 319 & 4.37 & 0.62 & & \\
\hline & 51 and over & 367 & 4.40 & 0.58 & & \\
\hline \multirow{4}{*}{$\begin{array}{l}\text { I monitor and document indicators of a } \\
\text { student's musical giftedness in class }\end{array}$} & 30 and under & 66 & 3.95 & 0.77 & \multirow{4}{*}{6.007} & \multirow{4}{*}{.111} \\
\hline & $31-40$ & 241 & 3.79 & 0.73 & & \\
\hline & $41-50$ & 286 & 3.86 & 0.72 & & \\
\hline & 51 and over & 317 & 3.92 & 0.70 & & \\
\hline \multirow{4}{*}{$\begin{array}{l}\text { I believe that. to identify musical } \\
\text { giftedness. it is necessary to use } \\
\text { measurement scales to check student } \\
\text { abilities in these areas }\end{array}$} & 30 and under & 65 & 3.91 & 0.77 & \multirow{4}{*}{1.786} & \multirow{4}{*}{.618} \\
\hline & $31-40$ & 238 & 3.82 & 0.76 & & \\
\hline & $41-50$ & 294 & 3.78 & 0.82 & & \\
\hline & 51 and over & 319 & 3.80 & 0.86 & & \\
\hline \multirow{4}{*}{$\begin{array}{l}\text { When I notice that a student is musically } \\
\text { gifted. I inform the school's expert } \\
\text { assistants }\end{array}$} & 30 and under & 66 & 3.91 & 0.92 & \multirow{4}{*}{4.951} & \multirow{4}{*}{.175} \\
\hline & $31-40$ & 240 & 3.73 & 0.94 & & \\
\hline & $41-50$ & 297 & 3.71 & 0.91 & & \\
\hline & 51 and over & 334 & 3.69 & 0.87 & & \\
\hline
\end{tabular}

Note. $M=$ average values; $S D=$ standard deviation; $H=$ Kruskal-Wallis $H$-test 
Teachers were divided into three groups according to their titles: teachers (A), teacher mentors (B), and teacher advisors (C). The results can be seen in Table 3 . The results demonstrated that, for teacher mentors, it is more important to encourage musically gifted students to attend additional curricular and extracurricular activities than it is for teachers from the first group. It is also more important for teacher mentors to spot a student's musical giftedness as early as possible. With the Kruskal-Wallis H-test, we checked whether the differences in responses in relation to the teaching title were significant at the .05 level. The results showed a statistically significant difference related to the importance of identifying students' musical giftedness as early as possible. Namely, a significant difference was found between the responses of teachers (A) and teacher mentors (B) $(H=12.670, p=<.001)$ according to which it can be concluded that teacher mentors are more aware of the importance of noticing students' musical giftedness as early as possible.

\section{Table 3}

Teachers' Opinions on the Importance of Procedures for Identifying Musical Giftedness in Relation to Their Title

\begin{tabular}{|c|c|c|c|c|c|c|}
\hline Statement & Teacher's title & $N$ & $M$ & $S D$ & $H$ & $p$ \\
\hline \multirow{3}{*}{$\begin{array}{l}\text { I encourage musically gifted students } \\
\text { to attend additional school and } \\
\text { extracurricular activities }\end{array}$} & Teacher & 736 & 4.46 & 0.61 & \multirow{3}{*}{13.095} & \multirow{3}{*}{.001} \\
\hline & Teacher mentor & 117 & 4.68 & 0.51 & & \\
\hline & Teacher advisor & 49 & 4.55 & 0.58 & & \\
\hline \multirow{3}{*}{$\begin{array}{l}\text { I think it is important to spot a student's } \\
\text { musical giftedness as early as possible }\end{array}$} & Teacher & 819 & 4.36 & 0.61 & \multirow{3}{*}{3.371} & \multirow{3}{*}{.185} \\
\hline & Teacher mentor & 130 & 4.45 & 0.59 & & \\
\hline & Teacher advisor & 60 & 4.45 & 0.07 & & \\
\hline \multirow{3}{*}{$\begin{array}{l}\text { I monitor and document indicators of a } \\
\text { student's musical giftedness in class }\end{array}$} & Teacher & 742 & 3.85 & 0.73 & \multirow{3}{*}{5.315} & \multirow{3}{*}{.070} \\
\hline & Teacher mentor & 118 & 3.99 & 0.69 & & \\
\hline & Teacher advisor & 50 & 3.96 & 0.64 & & \\
\hline \multirow{3}{*}{$\begin{array}{l}\text { I believe that. to identify musical } \\
\text { giftedness. it is necessary to use } \\
\text { measurement scales to check student } \\
\text { abilities in these areas }\end{array}$} & Teacher & 746 & 3.82 & 0.81 & \multirow{3}{*}{1.497} & \multirow{3}{*}{.473} \\
\hline & Teacher mentor & 120 & 3.78 & 0.85 & & \\
\hline & Teacher advisor & 50 & 3.72 & 0.86 & & \\
\hline \multirow{3}{*}{$\begin{array}{l}\text { When I notice that a student is musically } \\
\text { gifted. I inform the school's expert } \\
\text { assistants }\end{array}$} & Teacher & 764 & 3.72 & 0.90 & \multirow{3}{*}{0.387} & \multirow{3}{*}{.824} \\
\hline & Teacher mentor & 122 & 3.74 & 1.01 & & \\
\hline & Teacher advisor & 51 & 3.75 & 0.82 & & \\
\hline
\end{tabular}

Note. $M=$ average values; $S D=$ standard deviation; $H=$ Kruskal-Wallis $H$-test

In describing how they identify gifted students, teachers most often pointed out that they are able to identify them by their developed sense of rhythm and effortless performance of default rhythmic and melodic phrases. In their opinion, musically gifted students show great interest in singing, offer interesting solutions in rhythmic thinking, and easily improvise melodic phrases. They effortlessly remember melodies and play them with ease, while their intonation is very precise. Regarding the identification of musically gifted students, teachers also stated the following:

- Most often these are children who like to express themselves musically and like to sing. They very quickly and effortlessly embrace melody, rhythm and rhythmic phrases that need to be repeated. In essence, they demonstrate a special interest in music and their engagement in Music Culture classes is exceptional. 
PROBLEMS

OF EDUCATION

IN THE $21^{\text {st }}$ CENTURY Vol. 79 , No. 1,2021

144

- $\quad$ These children are musical, creative, they love musical activities, memorize melodies, have excellent hearing and beautiful vocal colour.

- $\quad$ The gifted child loves music, is interested in starting to play or is already playing an instrument, sings accurately and confidently reproduces songs, has a great sense of rhythm and is able to repeat any rhythmic structure.

- $\quad$ The gifted child reproduces the melody and rhythm very accurately. Independently and easily creates a melody for a given text. This melody, with its complexity and performance, stands out from the melodies created by other students. The gifted child also expresses what they hear through movement.

- Increased interest in music lessons. Happy when listening to music. Restless when listening to music (conducting, bouncing, dancing, imitating playing musical instruments, etc.). Often sings. Cracks fingers and produces other rhythmic sounds. Effortlessly memorizes melody and lyrics long-term. Plays music with unusual objects such as a pencil, straw, scissors, etc.

- $\quad$ A gifted child has a much bigger need to sing than other children. Loves to sing and does so with pleasure, confirming that he/she easily and accurately perceives the musical parts of songs, easily remembers the melody of the song, its tempo, dynamics, etc.

- $\quad$ Effortlessly memorizes more demanding melodies and enjoys them. Participates in musically oriented extracurricular activities. Attends music school. Plays an instrument.

- Demonstrates creative imagination and a sense of rhythmic and melodic musical improvisation. Imitates sounds from the environment by spontaneous improvisation. Freely creates dialogue using children's instruments. Composes a melody to a given sentence or verse.

- In identifying a musically gifted student, I follow these indicators: how expressively and melodically they perform different tunes; their sense of rhythm and ability to auditorily distinguish between songs with different tempos and dynamics; their motivation and progress and musical creativity or ability to independently solve certain tasks related to the creation of simple melodies or rhythmic units.

Teachers were then introduced to a group of statements related to the competencies for identifying and further developing musical giftedness in first-grade primary school students. Teachers were asked to express their agreement or disagreement with specific statements. Based on the obtained results it can be concluded that most teachers wished to be further educated in working with gifted students $(M=4.19 ; S D=0.78)$. Also, most teachers believed that, for working with a musically gifted student, it was necessary to expand and enrich the existing curriculum $(M=4.07 ; S D=0.74)$. About two-thirds of respondents stated that their activity encouraged the creativity of musically gifted students $(M=3.78 ; S D=0.77)$, while others stated that they were able to easily spot a musically gifted student in class $(M=3.76 ; S D=0.77)$ and that they sought the assistance and support of expert assistants (psychologists and pedagogues) in confirming their assessment of a musically gifted student $(M=3.60 ; S D=0.99)$. Slightly less than half of the teachers $(M=3.41 ; S D=0.87)$ implemented curriculum enrichment (in depth and in breadth), as a method of working with gifted children, while slightly more than a third of them $(M=3.30 ; S D=0.85)$ considered themselves competent enough to assess a musically gifted student. Less than half of the teachers were familiar with Gardner's Theory of Multiple Intelligences $(M=3.29 ; S D=1.16)$ (Figure 2). The greatest standard deviation was obtained in the answers about the knowledge of Gardner's theory $(S D=1.16)$, and the lowest value of dispersion in the answers regarding the need to expand and enrich the existing curriculum $(S D$ $=0.74)$. 


\section{Figure 2}

Self-Assessment of Teachers' Competencies for the Identification and Further Development of Gifted Students (Average Values of Teacher Opinions (M))

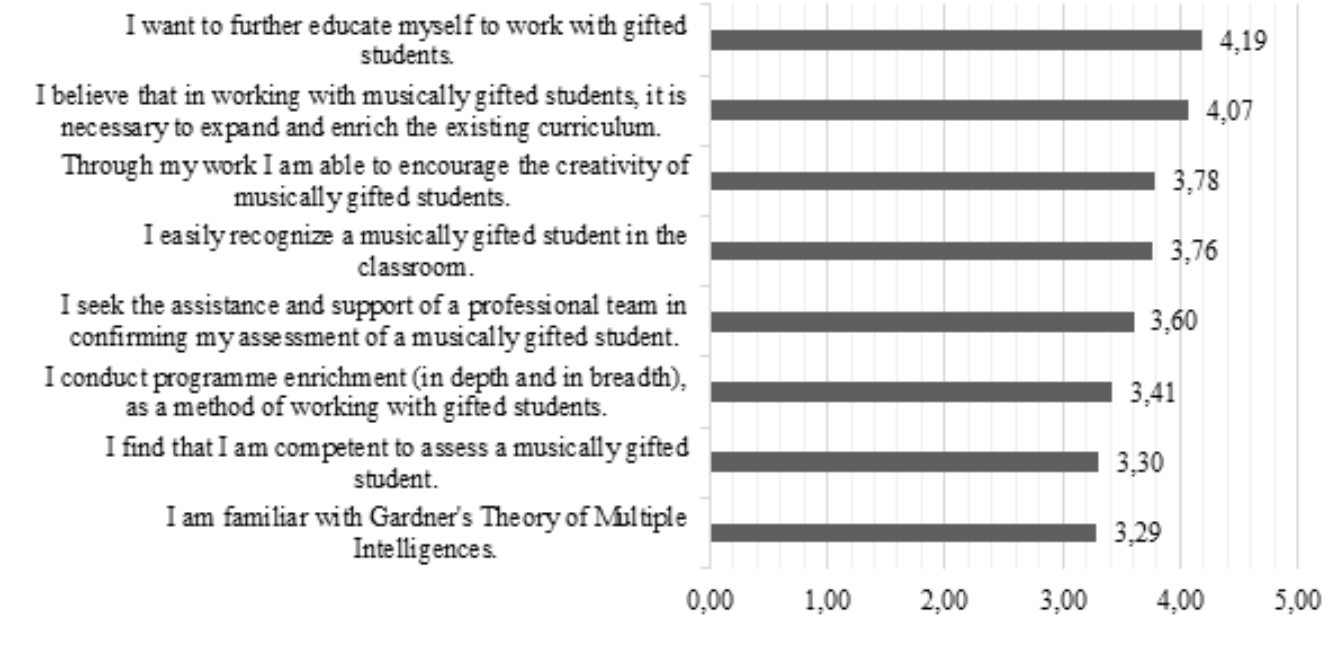

Given the age of the teachers, the results demonstrated that the youngest teachers showed greater agreement with most of the statements compared to the teachers from the other three age groups (Table 4). When it comes to expressing a desire for additional training in working with gifted students, the difference was statistically significant between the responses of teachers from the first and fourth group (teachers aged 30 or under and teachers aged 51 or over) in favour of teachers aged 30 or under $(H=10.751, p=.001)$, the second and fourth group (teachers aged 31 to 40 and teachers aged 51 or over) in favour of teachers aged 31 to $40(H=10.618, p=.001)$, and the third and fourth group (teachers aged 41 to 50 and teachers aged 51 or over) in favour of teachers aged 41 to $50(H=7.511, p=.006)$. The youngest teachers also expressed a higher need to expand and enrich the existing curriculum for working with musically gifted students. In these responses, the differences were statistically significant between the first and second group (teachers aged 30 or under and teachers aged 31 to 40$)(H=5.165, p=.023)$, the first and third group (teachers aged 30 or under and teachers aged 41 to 50$)(H=10.873, p=.001)$ and the first and fourth group (teachers aged 30 or under and teachers aged 51 or over) $(H=7.147$, $p=.008)$. In all three cases, the difference was in favour of teachers aged 30 and younger. The youngest teachers were best acquainted with Gardner's Theory of Multiple Intelligences. When it comes to this issue, statistically significant differences were found between the answers of teachers from the first and second group (teachers aged 30 or under and teachers aged 31 to 40) in favour of teachers aged 30 or under $(H=4.097, p=.043)$, the first and third group (teachers aged 30 or under and teachers aged 41 to 50$)$ in favour of teachers aged 20 or under $(H=7.388$, $p=.007$ ), and the third and fourth group (teachers aged 41 to 50 and teachers aged 51 or over) in favour of teacher aged 51 or over $(H=4.645, p=.031)$. 
Vesna SVALINA, Blaženka BAČLIJA SUŠIĆ, Goran LAPAT. Primary school teachers' opinions towards musically gifted students

PROBLEMS

OF EDUCATION

IN THE $21^{\text {st }}$ CENTURY

Vol. 79 , No. 1,202

146

Table 4

Teachers' Opinions on Their Competencies for Identifying Musical Giftedness, in Relation to Their Age

\begin{tabular}{|c|c|c|c|c|c|c|}
\hline Statement & Teacher's age & $N$ & $M$ & $S D$ & $H$ & $p$ \\
\hline \multirow{4}{*}{$\begin{array}{l}\text { I want to further educate myself to work } \\
\text { with gifted students }\end{array}$} & 30 and under & 50 & 4.46 & 0.54 & \multirow{4}{*}{18.613} & \multirow{4}{*}{$<.001$} \\
\hline & $31-40$ & 193 & 4.28 & 0.73 & & \\
\hline & $41-50$ & 242 & 4.24 & 0.72 & & \\
\hline & 51 and over & 275 & 4.03 & 0.87 & & \\
\hline \multirow{4}{*}{$\begin{array}{l}\text { I believe that in working with musically } \\
\text { gifted students, it is necessary to expand } \\
\text { and enrich the existing curriculum }\end{array}$} & 30 and under & 49 & 4.37 & 0.67 & \multirow{4}{*}{12.314} & \multirow{4}{*}{.006} \\
\hline & $31-40$ & 180 & 4.13 & 0.66 & & \\
\hline & $41-50$ & 241 & 3.98 & 0.77 & & \\
\hline & 51 and over & 264 & 4.06 & 0.77 & & \\
\hline \multirow{4}{*}{$\begin{array}{l}\text { Through my work I am able to encourage } \\
\text { the creativity of musically gifted students }\end{array}$} & 30 and under & 49 & 3.84 & 0.87 & \multirow{4}{*}{0.738} & \multirow{4}{*}{.864} \\
\hline & $31-40$ & 174 & 3.79 & 0.80 & & \\
\hline & $41-50$ & 235 & 3.78 & 0.76 & & \\
\hline & 51 and over & 262 & 3.76 & 0.73 & & \\
\hline \multirow{4}{*}{$\begin{array}{l}\text { I easily recognize a musically gifted } \\
\text { student in the classroom }\end{array}$} & 30 and under & 49 & 3.84 & 0.69 & \multirow{4}{*}{6.043} & \multirow{4}{*}{.110} \\
\hline & $31-40$ & 199 & 3.67 & 0.76 & & \\
\hline & $41-50$ & 257 & 3.74 & 0.81 & & \\
\hline & 51 and over & 294 & 3.82 & 0.74 & & \\
\hline \multirow{4}{*}{$\begin{array}{l}\text { I seek the assistance and support of } \\
\text { a professional team in confirming my } \\
\text { assessment of a musically gifted student }\end{array}$} & 30 and under & 49 & 3.57 & 0.96 & \multirow{4}{*}{4.255} & \multirow{4}{*}{.235} \\
\hline & $31-40$ & 180 & 3.64 & 0.87 & & \\
\hline & $41-50$ & 239 & 3.49 & 1.02 & & \\
\hline & 51 and over & 268 & 3.66 & 1.04 & & \\
\hline \multirow{4}{*}{$\begin{array}{l}\text { I conduct programme enrichment (in } \\
\text { depth and in breadth), as a method of } \\
\text { working with gifted students }\end{array}$} & 30 and under & 50 & 3.50 & 0.86 & \multirow{4}{*}{2.707} & \multirow{4}{*}{.439} \\
\hline & $31-40$ & 191 & 3.38 & 0.87 & & \\
\hline & $41-50$ & 241 & 3.36 & 0.88 & & \\
\hline & 51 and over & 277 & 3.47 & 0.86 & & \\
\hline \multirow{4}{*}{$\begin{array}{l}\text { I find that I am competent to assess a } \\
\text { musically gifted student }\end{array}$} & 30 and under & 48 & 3.40 & 0.84 & \multirow{4}{*}{3.165} & \multirow{4}{*}{.367} \\
\hline & $31-40$ & 181 & 3.22 & 0.85 & & \\
\hline & $41-50$ & 242 & 3.30 & 0.88 & & \\
\hline & 51 and over & 269 & 3.35 & 0.84 & & \\
\hline \multirow{4}{*}{$\begin{array}{l}\text { I am familiar with Gardner's Theory of } \\
\text { Multiple Intelligences }\end{array}$} & 30 and under & 50 & 3.66 & 1.17 & \multirow{4}{*}{9.822} & \multirow{4}{*}{$<.001$} \\
\hline & $31-40$ & 198 & 3.28 & 1.16 & & \\
\hline & $41-50$ & 256 & 3.13 & 1.23 & & \\
\hline & 51 and over & 295 & 3.38 & 1.07 & & \\
\hline
\end{tabular}

Note. $M=$ average values; $S D=$ standard deviation; $H=$ Kruskal-Wallis $H$-test

When dividing teacher answers according to their titles - teacher (A), teacher mentor (B), teacher advisor (C) - it was noticed that the average values were higher in the answers of teachers from the second and third group than in the answers of teachers from the first group 
(Table 5). The difference was statistically significant in the answers to the question concerning the need for additional training for working with gifted students given by teachers and advisor teachers $(H=5.044, p=.025)$, in favour of advisor teachers, and in the answers to the question concerning the implementation of curriculum enrichment (in depth and breadth) as a method of working with gifted students given by teachers and advisor teachers $(H=7.427, p=0.006)$. The difference was, once more, in favour of advisor teachers. A statistically significant difference was found in the answers concerning the knowledge of Gardner's Theory of Multiple Intelligences between teachers and advisor teachers $(H=22.720, p=<.000)$, in favour of advisor teachers, i.e., between mentor teachers and advisor teachers $(H=10.819, p=.001)$, also in favour of advisor teachers.

\section{Table 5}

Teachers' Opinions on Their Competencies for Identifying Musical Giftedness, in Relation to Their Title

\begin{tabular}{|c|c|c|c|c|c|c|}
\hline Statement & Teacher's title & $N$ & $M$ & $S D$ & $H$ & $p$ \\
\hline \multirow{3}{*}{$\begin{array}{l}\text { I want to further educate myself to work } \\
\text { with gifted students }\end{array}$} & Teacher & 604 & 4.15 & 0.80 & \multirow{3}{*}{7.426} & \multirow{3}{*}{.024} \\
\hline & Teacher mentor & 106 & 4.30 & 0.71 & & \\
\hline & Teacher advisor & 50 & 4.42 & 0.61 & & \\
\hline \multirow{3}{*}{$\begin{array}{l}\text { I believe that in working with musically } \\
\text { gifted students, it is necessary to } \\
\text { expand and enrich the existing } \\
\text { curriculum }\end{array}$} & Teacher & 580 & 4.05 & 0.74 & \multirow{3}{*}{2.309} & \multirow{3}{*}{.309} \\
\hline & Teacher mentor & 104 & 4.14 & 0.78 & & \\
\hline & Teacher advisor & 50 & 4.12 & 0.66 & & \\
\hline \multirow{3}{*}{$\begin{array}{l}\text { Through my work I am able to } \\
\text { encourage the creativity of musically } \\
\text { gifted students }\end{array}$} & Teacher & 569 & 3.76 & 0.79 & \multirow{3}{*}{4.602} & \multirow{3}{*}{.100} \\
\hline & Teacher mentor & 103 & 3.92 & 0.68 & & \\
\hline & Teacher advisor & 48 & 3.71 & 0.71 & & \\
\hline \multirow{3}{*}{$\begin{array}{l}\text { I easily recognize a musically gifted } \\
\text { student in the classroom }\end{array}$} & Teacher & 634 & 3.75 & 0.77 & \multirow{3}{*}{1.064} & \multirow{3}{*}{.587} \\
\hline & Teacher mentor & 113 & 3.81 & 0.79 & & \\
\hline & Teacher advisor & 51 & 3.76 & 0.76 & & \\
\hline \multirow{3}{*}{$\begin{array}{l}\text { I seek the assistance and support } \\
\text { of a professional team in confirming } \\
\text { my assessment of a musically gifted } \\
\text { student }\end{array}$} & Teacher & 585 & 3.63 & 0.96 & \multirow{3}{*}{4.846} & \multirow{3}{*}{.089} \\
\hline & Teacher mentor & 103 & 3.37 & 1.16 & & \\
\hline & Teacher advisor & 48 & 3.73 & 0.89 & & \\
\hline \multirow{3}{*}{$\begin{array}{l}\text { I conduct programme enrichment (in } \\
\text { depth and in breadth), as a method of } \\
\text { working with gifted students }\end{array}$} & Teacher & 602 & 3.38 & 0.87 & \multirow{3}{*}{7.838} & \multirow{3}{*}{.020} \\
\hline & Teacher mentor & 107 & 3.45 & 0.92 & & \\
\hline & Teacher advisor & 50 & 3.74 & 0.75 & & \\
\hline \multirow{3}{*}{$\begin{array}{l}\text { I find that I am competent to assess a } \\
\text { musically gifted student }\end{array}$} & Teacher & 588 & 3.28 & 0.85 & \multirow{3}{*}{1.536} & \multirow{3}{*}{.464} \\
\hline & Teacher mentor & 103 & 3.34 & 0.89 & & \\
\hline & Teacher advisor & 49 & 3.43 & 0.87 & & \\
\hline \multirow{3}{*}{$\begin{array}{l}\text { I am familiar with Gardner's Theory of } \\
\text { Multiple Intelligences }\end{array}$} & Teacher & 631 & 3.23 & 1.15 & \multirow{3}{*}{22.848} & \multirow{3}{*}{$\begin{array}{l}p< \\
0.001\end{array}$} \\
\hline & Teacher mentor & 113 & 3.35 & 1.19 & & \\
\hline & Teacher advisor & 54 & 3.96 & 0.95 & & \\
\hline
\end{tabular}

Note. $M=$ average values; $S D=$ standard deviation; $H=$ Kruskal-Wallis $H$-test

PROBLEMS

OF EDUCATION

IN THE $21^{\text {st }}$ CENTURY

Vol. 79, No. 1, 2021

147 
Vesna SVALINA, Blaženka BAČLIJA SUŠIĆ, Goran LAPAT. Primary school teachers' opinions towards musically gifted students

PROBLEMS

OF EDUCATION

IN THE $21^{\text {st }}$ CENTURY

Vol. 79, No. 1,2021

The answers in which teachers indicated their level of agreement (or disagreement) with the statements that referred to the conditions provided to musically gifted students with regard to the support of family/parents and expert assistants (psychologists and pedagogues) (Figure $3)$, demonstrated that the majority of teachers $(M=4.07 ; S D=0.78)$ believed that they needed more support from the expert assistants in working with gifted students and slightly more than half of the teachers $(M=3.67 ; S D=0.93)$ indicated that they needed more support from the principal. The majority of teachers $(M=3.86 ; S D=0.76)$ believed that families encouraged and supported musically gifted students and that the schools in which they worked were interested in encouraging the development of musical giftedness in students $(M=3.46 ; S D=0.94)$. One-third of teachers were not satisfied with the tracking of musically gifted students at the school level $(M=2.91 ; S D=0.99)$, and half of the teachers indicated that there was no special curriculum for working with gifted students at their school $(M=2.53 ; S D=1.23)$. The results showed the largest standard deviation in teachers' answers regarding the existence of a special curriculum for working with gifted students $(S D=1.23)$, and the lowest value of dispersion in answers concerning the support that musically gifted students had in their families $(S D=0.76)$.

\section{Figure 3}

Teachers' Opinions on the Conditions for the Encouragement and Development of Gifted Students (Average Values of Teacher Opinions (M))

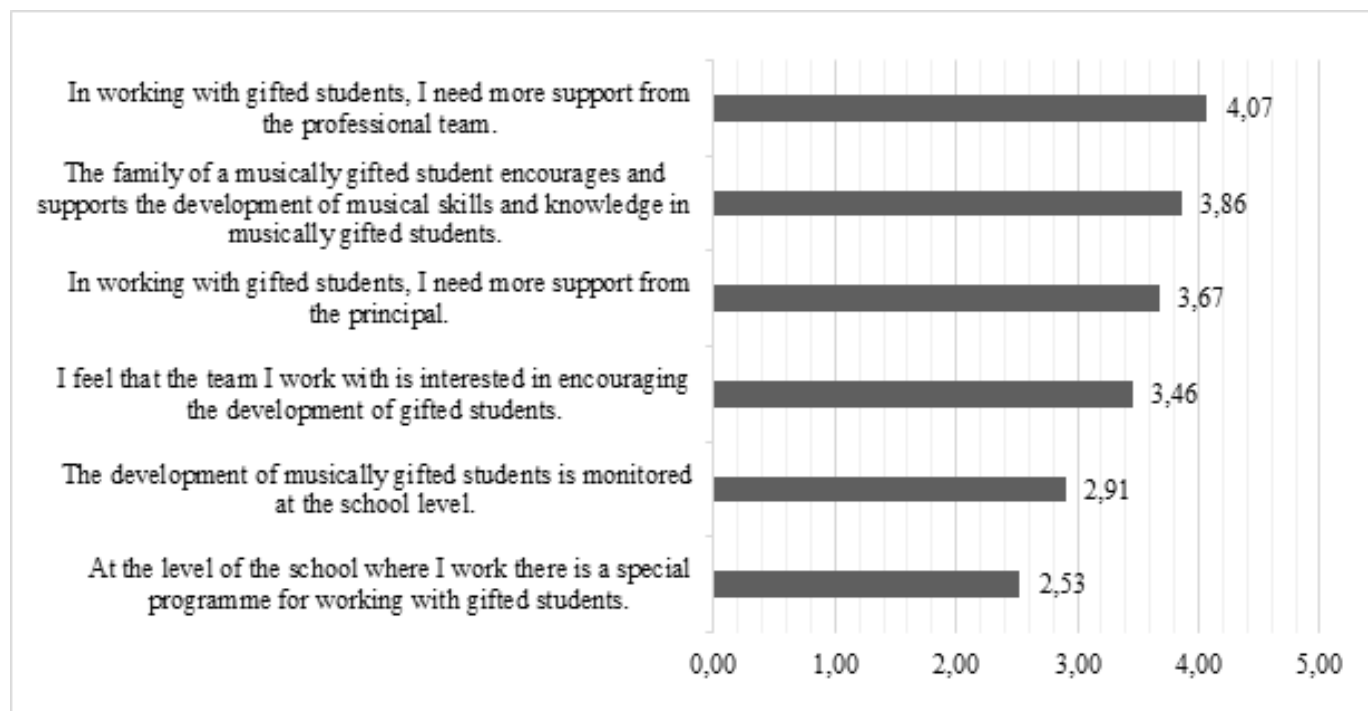

After comparing teacher responses in relation to their age, the following results, shown in Table 6, were obtained. The differences were found to be statistically significant in teacher responses related to the family support of musically gifted students, between the first and the second group (teachers aged 30 or under and teachers aged 31 to 40), in favour of teachers aged 30 or under $(H=6.344, p=.012)$, the second and fourth group (teachers aged 31 to 40 and teachers aged 51 or over), in favour of teachers aged 51 or over $(H=10.020, p=0.002)$, and the third and fourth group (teachers aged 41 to 50 and teachers aged 51 or over), in favour of teacher aged 51 or over $(H=4.924, p=.026)$, and the difference between the first and third group (teachers aged 30 or under and teachers aged 41 to 50 ) was bordering on significant, in favour of teachers aged 30 or under $(H=3.749, p=.053)$. A difference was also found in the responses concerning the existence of a special curriculum for working with gifted students at the school level. It is here that the largest standard deviation in answers was observed (A - SD $=1.17 ; \mathrm{B}-S D=1.19 ; \mathrm{C}-S D=1.28 ; \mathrm{D}-S D=1.19)$. A statistically significant difference was 
found in the responses of teachers from the second and third group (teachers aged 31 to 40 and teachers aged 41 to 50$)$, in favour of teachers aged 41 to $50(H=8.164, p=.004)$, and the difference in the responses of teachers from the third and fourth group (teachers aged 41 to 50 and teachers aged 51 or over) was bordering on significant, in favour of teachers aged 41 to 50 $(H=3.596, p=.058)$.

\section{Table 6}

Teachers' Opinions on the Conditions for the Encouragement and Development of Gifted Students in Relation to Their Age

\begin{tabular}{|c|c|c|c|c|c|c|}
\hline Statement & Teacher's age & $N$ & $M$ & $S D$ & $H$ & $p$ \\
\hline \multirow{4}{*}{$\begin{array}{l}\text { In working with gifted students, I need } \\
\text { more support from the professional team }\end{array}$} & 30 and under & 49 & 3.96 & 0.89 & \multirow{4}{*}{2.083} & \multirow{4}{*}{.555} \\
\hline & $31-40$ & 187 & 4.05 & 0.75 & & \\
\hline & $41-50$ & 253 & 4.04 & 0.78 & & \\
\hline & 51 and over & 289 & 4.11 & 0.77 & & \\
\hline \multirow{4}{*}{$\begin{array}{l}\text { The family of a musically gifted } \\
\text { student encourages and supports the } \\
\text { development of musical skills and } \\
\text { knowledge in musically gifted students }\end{array}$} & 30 and under & 48 & 4.06 & 0.76 & \multirow{4}{*}{13.724} & \multirow{4}{*}{.003} \\
\hline & $31-40$ & 184 & 3.74 & 0.73 & & \\
\hline & $41-50$ & 244 & 3.81 & 0.77 & & \\
\hline & 51 and over & 288 & 3.94 & 0.76 & & \\
\hline \multirow{4}{*}{$\begin{array}{l}\text { In working with gifted students, I need } \\
\text { more support from the principal }\end{array}$} & 30 and under & 48 & 3.69 & 1.04 & \multirow{4}{*}{3.603} & \multirow{4}{*}{.308} \\
\hline & $31-40$ & 182 & 3.78 & 0.87 & & \\
\hline & $41-50$ & 244 & 3.64 & 0.94 & & \\
\hline & 51 and over & 273 & 3.62 & 0.93 & & \\
\hline \multirow{4}{*}{$\begin{array}{l}\text { I feel that the team I work with } \\
\text { is interested in encouraging the } \\
\text { development of gifted students }\end{array}$} & 30 and under & 48 & 3.60 & 0.98 & \multirow{4}{*}{6.640} & \multirow{4}{*}{.084} \\
\hline & $31-40$ & 183 & 3.45 & 0.99 & & \\
\hline & $41-50$ & 246 & 3.36 & 0.91 & & \\
\hline & 51 and over & 267 & 3.51 & 0.92 & & \\
\hline \multirow{4}{*}{$\begin{array}{l}\text { The development of musically gifted } \\
\text { students is monitored at the school level }\end{array}$} & 30 and under & 49 & 3.10 & 0.87 & \multirow{4}{*}{3.519} & \multirow{4}{*}{.318} \\
\hline & $31-40$ & 187 & 2.86 & 0.96 & & \\
\hline & $41-50$ & 250 & 2.86 & 1.02 & & \\
\hline & 51 and over & 297 & 2.95 & 1.01 & & \\
\hline \multirow{4}{*}{$\begin{array}{l}\text { At the level of the school where I work } \\
\text { there is a special programme for working } \\
\text { with gifted students }\end{array}$} & 30 and under & 48 & 2.46 & 1.17 & \multirow{4}{*}{8.848} & \multirow{4}{*}{.031} \\
\hline & $31-40$ & 181 & 2.36 & 1.19 & & \\
\hline & $41-50$ & 241 & 2.72 & 1.28 & & \\
\hline & 51 and over & 270 & 2.50 & 1.19 & & \\
\hline
\end{tabular}

Note. $M=$ average values; $S D=$ standard deviation; $H=$ Kruskal-Wallis $H$-test

The answers concerning the conditions for the encouragement and development of musical knowledge and skills in musically gifted students were compared in relation to the titles of the teachers: teacher (A), teacher mentor (B), teacher advisor (C). The responses of all three groups were fairly uniform (Table 7). A statistically significant difference was found only in answers concerning the tracking of the development of musically gifted students at the level of the school in the answers given by the teachers from the first (A) and the second (B) group (teachers and mentor teachers), in favour of teachers $(H=5.889, p=.015)$. Hence, teacher mentors were the least satisfied with the tracking of musically gifted students at the school level.

PROBLEMS

OF EDUCATION

IN THE $21^{\text {st }}$ CENTURY

Vol. 79, No. 1, 2021 
Vesna SVALINA, Blaženka BAČLIJA SUŠIĆ, Goran LAPAT. Primary school teachers' opinions towards musically gifted students

PROBLEMS

OF EDUCATION

IN THE $21^{\text {st }}$ CENTURY Vol. 79 , No. 1,2021

Table 7

Teachers' Opinions on the Conditions for the Encouragement and Development of Gifted Students in Relation to Their Title

\begin{tabular}{|c|c|c|c|c|c|c|}
\hline Statement & Teacher's title & $N$ & $M$ & $S D$ & $H$ & $p$ \\
\hline \multirow{3}{*}{$\begin{array}{l}\text { In working with gifted students, I need } \\
\text { more support from the professional } \\
\text { team }\end{array}$} & Teacher & 615 & 4.05 & 0.77 & \multirow{3}{*}{2.062} & \multirow{3}{*}{.357} \\
\hline & Teacher mentor & 111 & 4.08 & 0.83 & & \\
\hline & Teacher advisor & 53 & 4.21 & 0.72 & & \\
\hline \multirow{3}{*}{$\begin{array}{l}\text { The family of a musically gifted } \\
\text { student encourages and supports the } \\
\text { development of musical skills and } \\
\text { knowledge in musically gifted students }\end{array}$} & Teacher & 604 & 3.85 & 0.76 & \multirow{3}{*}{0.292} & \multirow{3}{*}{.864} \\
\hline & Teacher mentor & 109 & 3.88 & 0.74 & & \\
\hline & Teacher advisor & 51 & 3.86 & 0.85 & & \\
\hline \multirow{3}{*}{$\begin{array}{l}\text { In working with gifted students, I need } \\
\text { more support from the principal }\end{array}$} & Teacher & 596 & 3.64 & 0.94 & \multirow{3}{*}{1.837} & \multirow{3}{*}{.399} \\
\hline & Teacher mentor & 104 & 3.74 & 0.92 & & \\
\hline & Teacher advisor & 48 & 3.81 & 0.76 & & \\
\hline \multirow{3}{*}{$\begin{array}{l}\text { I feel that the team I work with } \\
\text { is interested in encouraging the } \\
\text { development of gifted students }\end{array}$} & Teacher & 589 & 3.48 & 0.93 & \multirow{3}{*}{2.639} & \multirow{3}{*}{.267} \\
\hline & Teacher mentor & 106 & 3.37 & 0.98 & & \\
\hline & Teacher advisor & 50 & 3.34 & 0.92 & & \\
\hline \multirow{3}{*}{$\begin{array}{l}\text { The development of musically gifted } \\
\text { students is monitored at the school } \\
\text { level }\end{array}$} & Teacher & 620 & 2.96 & 0.99 & \multirow{3}{*}{7.310} & \multirow{3}{*}{.026} \\
\hline & Teacher mentor & 111 & 2.72 & 1.03 & & \\
\hline & Teacher advisor & 52 & 2.75 & 0.97 & & \\
\hline \multirow{3}{*}{$\begin{array}{l}\text { At the level of the school where I } \\
\text { work there is a special programme for } \\
\text { working with gifted students }\end{array}$} & Teacher & 588 & 2.53 & 1.23 & \multirow{3}{*}{1.263} & \multirow{3}{*}{.532} \\
\hline & Teacher mentor & 104 & 2.62 & 1.19 & & \\
\hline & Teacher advisor & 49 & 2.43 & 1.32 & & \\
\hline
\end{tabular}

Note. $M=$ average values; $S D=$ standard deviation; $H=$ Kruskal-Wallis $H$-test

\section{Discussion}

Even though gifted children are often emphasized as the treasure and wealth of any society, it seems that the issue of giftedness is still not given enough attention in educational practice. The results of the research aimed at determining the state of this subject in Croatian primary schools, in terms of the development of musical giftedness in students attending the first four grades of primary school based on the opinion of primary school classroom teachers, are potentially worrisome for all gifted students.

The results of the survey conducted among teachers teaching the first four primary school grades indicated that, in the past school year, the largest number of teachers identified one $(18.6 \%)$, two $(21.9 \%)$ or three $(12.8 \%)$ students, while some teachers did not recognize any musically gifted students. The obtained results had been confirmed by the results of another study, also conducted in Croatia (Nikčević-Milković et al., 2019), which also indicated low levels of identification of gifted students by primary school teachers. The poor ability of teachers to identify gifted students was confirmed by research studies in the field of art, according to which only $10 \%$ of teachers were able to identify artistically gifted children (Brajčić et al., 2020; Duh \& Lep, 2008).

In general, a small percentage of gifted students in schools is identified. In one of the conducted case studies regarding the context of gifted and talented, Robinson and Campbell (2010) stated that "DfES (Department for Education and Skills) guidelines suggest that each 
school identified 5-10 percent of students in each group year as gifted and talented, regardless of the institution's profile ability" (Robinson \& Campbell, 2010, p. 94).

The low level of recognition of gifted students in the first four grades of primary school is attributed primarily to the insufficient competencies of teachers. The teachers' insufficient knowledge about gifted students results in the fact that some teachers are not able to identify a gifted student in a classroom, although they are aware that identification procedures are of key importance for the furthering of procedures in the nurturing and development of musical giftedness in students.

In describing how they identify gifted students, teachers most often pointed out that they were able to identify them by their developed sense of rhythm and effortless performance of default rhythmic and melodic phrases, showing great interest in singing, offer interesting solutions in rhythmic thinking and easily improvise melodic phrases. They effortlessly remember melodies and always play them with ease, while their intonation is very precise. In addition to these indicators of musical sensibility and a strong interest in music, as a key indicator of musical giftedness Davis et al. (2014) pointed out: the child's intuitive knowledge of musical parameters, the ability to recognize the expressive properties of sound and strong musical memory, the child's manner of talking about music, his intense responses when listening to music and expressing unusual and creative observations about music.

The largest number of respondents emphasized the importance of early identification (95.79\%) and guiding and encouraging a musically gifted child to attend additional curricular and extracurricular activities (95.79\%). The results obtained in connection with the teachers' title indicated the existence of a statistically significant difference between teachers and mentor teachers when it came to their views on the importance of early identification of student musical giftedness. The results also indicated that mentor teachers were more aware of the importance of early identification of a child's giftedness and emphasized the importance of encouraging gifted students to attend additional curricular and extracurricular activities more than teachers without special titles.

Starting from the point of view that teacher's title is related to their education and general work motivation it is also assumed that teachers with higher titles have more work experience and pay more attention to various forms of additional professional development. The results of a study on the positivity, negativity and ambivalence of teacher attitudes towards working with gifted students, conducted by Čudina-Obradović and Posavec (2009), showed that teacher attitudes depend on their personal experience in working with gifted students and that more positive attitudes can be attributed to teachers who are more satisfied, more preoccupied with work, and have more work experience. Additionally, they assumed that teacher's attitudes about working with gifted children are largely dependent on their general satisfaction with their work and their commitment to their vocation.

Likewise, a teacher's title often relates to their motivation to improve their competencies and motivation for lifelong learning, which may include working with gifted children. In the research investigating teacher motivation for working with musically gifted students, it was found that additional music education of teachers was a significant factor that influenced their motivation to work with musically gifted students and that working with gifted children was a challenge for them, regardless of their status (Radičević et al., 2013).

Given the age of the respondents, younger respondents expressed a greater desire for additional training in working with gifted students and also a greater need to expand and enrich the existing curriculum for working with musically gifted students. Also, the obtained results indicated that the youngest teachers were better acquainted with Gardner's Theory of Multiple Intelligences than their older colleagues. Although there was no statistically significant difference among respondents with respect to their age, it was found that higher scores in favour of older respondents reflected their attitudes towards encouraging students to attend additional curricular and extracurricular activities. 
PROBLEMS

OF EDUCATION IN THE $21^{\text {st }}$ CENTURY Vol. 79 , No. 1,2021

152

The results obtained by Nikčević-Milković et al. (2016) demonstrated that younger teachers (with fewer years of experience) try harder to encourage gifted and talented students and use different programs, methods and forms of work, whilst directly caring for them and participating in their identification. Research shows that teacher effectiveness, given their work experience, is on the rise mostly during the early years of their careers, but that this growth continues in the second and often third decade of their careers (Podolsky et al., 2019).

The results of previous studies indicate that age and years of teaching are often associated with different attitudes toward the gifted, and the differences between the attitudes of beginners and experienced teachers have also often been confirmed (Koren, 1996; Posavec, 2008). However, study results vary when it comes to age. Despite that, some studies have shown that younger teachers have a more positive attitude (Tomlinson et al., 2004). It was also found that teachers with more work experience view gifted children in a more realistic way and describe them more positively and concisely than teachers with no work experience (Endepohls-Ulpe, 2004).

Regarding the level of self-assessment of teacher competencies for the identification and further development of gifted students in Year 1 primary school students, most teachers (85.28\%) expressed a desire for further training in working with gifted students. At the same time, in working with musically gifted students, most teachers (82.59\%) considered it necessary to expand and enrich the existing curriculum.

In accordance with other conducted research, some authors state that it is extremely important to develop competencies for identifying gifted individuals in these areas. Their identification and education stand out as two basic issues when working with gifted students. Teachers, who are expected to be professionally trained and to have sufficient knowledge about giftedness, i.e., to have developed competencies for the identification and work with gifted children, have a particularly significant role in the matter (Gojkov \& Stojanović, 2014).

According to the conditions for encouraging and developing musical knowledge and skills in musically gifted students, with regard to the support of their parents, expert assistants and collective, the majority of teachers $(79.97 \%)$ considered that they needed more support from the expert assistants in working with gifted students. Most of them (75\%) stated that the schools in which they were employed were interested in encouraging the development of musical giftedness in students while in terms of family support, $70.59 \%$ of teachers believed that families did encourage and support musically gifted students.

Numerous authors have emphasised that the family, school and cultural context influence the manifestation of the characteristics of gifted individuals in a special way (Neihart et al., 2002; Reis \& Renzulli, 2004). There are conflicting views regarding the social and emotional needs of gifted students. While on the one hand gifted students are considered to have unique social and emotional needs, on the other hand, it is stated that their emotional and social adjustment is better than that of the general population (Plucker \& Callahan, 2014).

Working with gifted students is, in any case, a particularly important area of education, especially during a child's developmental period which is most important for actualizing a child's potential giftedness. The child's family and teacher play particularly important roles, as does the effort and the attitude of the environment towards the child's giftedness in general.

It is emphasized that children's abilities only gain real value in relation to their parents and other people in their lives (Sutherland, 2015). A large number of gifted children fail to develop their potential and giftedness precisely because they never receive adequate support. Although parents are the most important source of information about the child's potential giftedness and have a significant impact on the development of the child's musical abilities, at the same time they expect teachers to identify and meet the developmental and educational needs of all children, i.e., to meet their current capabilities and develop their potentials (Gojkov \& Stojanović, 2014). The same authors emphasized the issue of poor cooperation between a 
small number of teachers and parents, as well as insufficient time that is set aside for working with gifted students, the lack of teaching aids in the languages of national minorities, and so on.

A special contribution to the development of musical giftedness is made by specialized music teachers. In addition to identifying student strengths based on communication with other adults and seeking different approaches to enrich the student's environment (Abramo \& NataleAbramo, 2020), their collaboration with primary school teachers is of particular importance.

\section{Conclusions}

Regardless of the fact that in conceptualizing musical giftedness, respondents cite numerous indicators such as: developed sense of rhythm and performance of given rhythmic and melodic phrases, expressed interest in singing and ease in improvising melodic phrases as well as ease in its remembering and playing, there has been found a low level of recognition of musically gifted students. Moreover, some respondents were not able to recognize gifted students in the classroom at all. This can further be attributed to their insufficient competencies for identification of musically gifted students. Given the satisfaction of respondents with their competencies for recognizing and further developing gifted students, the results obtained confirmed that teacher-mentors are the least satisfied with their ability to track musically gifted children. In the self-assessment of competencies for the identification and further development of gifted students, most of the respondents, expressed a desire for further training to work with gifted students. Particular emphasis is placed on younger respondents who expressed a greater desire for additional training to work with gifted students as well as a greater need to expand and enrich the existing curriculum for working with musically gifted students. Also, it was established that the majority of respondents believe that they need more support from expert assistants in working with gifted students and state that they have support from the school where they are employed as well as parents of gifted children.

The results obtained confirmed that there is a need to empower teachers to identify the musical giftedness of students through special programs in teacher education, organizing different forms of additional music education in form of seminars and workshops, and other similar activities in order to be more competent in identifying musically gifted children.

Systematic work with the musically gifted children is an educational activity that is generally important because it mediates during the developmental period that is critical for the actualization of child's musical potential. Accordingly, it is especially important that teachers in the first grades of primary school identify musically gifted students and refer them to additional music education within music schools. Hence teachers should not leave the identification and encouragement of musically gifted students to specialized music teachers who, in the education system in the Republic of Croatia, start working with primary school students at the fourth grade of primary school.

Furthermore, teachers who work with gifted students and those that are trained on how to encourage their creative, artistic and scientific thinking, or help these students understand themselves, their self-concept, and acquire quality education and career achievements, at the same time become better teachers.

Findings of this research have theoretical and practical implications for further research focused on the issue of children's musical giftedness in the context of lower primary school. Additionally, the results obtained represent implications for teachers better understanding, identifying, and further development musically gifted. Moreover, it will contribute to advancement of teacher's musical competencies both during their studies as well as during their lifelong education.

\author{
PROBLEMS \\ OF EDUCATION \\ IN THE $21^{\text {st }}$ CENTURY \\ Vol. 79 , No. 1,2021 \\ 153
}


Vesna SVALINA, Blaženka BAČLIJA SUŠIĆ, Goran LAPAT. Primary school teachers' opinions towards musically gifted students

PROBLEMS

OF EDUCATION

IN THE $21^{\text {st }}$ CENTURY Vol. 79 , No. 1,202

\section{Acknowledgements}

This paper presents a part of the results of the research conducted within the project "Giftedness in the artistic field - analysis of the situation among primary school pupils in terms of artistic and musical giftedness." The project was implemented as part of bilateral cooperation between Croatia and Slovenia from 2017 to 2019 and was funded by the Ministries of Education of the two countries. The project leader on the Croatian side was prof. dr. Milan Matijević (from the Faculty of Teacher Education in Zagreb), and prof. dr. Matjaž Duh (from the Faculty of Education in Maribor) from the Slovenian side.

\section{References}

Abramo, J. M., \& Abramo, M. N. (2020). Reexamining "gifted and talented" in music education. Music Educators Journal, 106(3), 38-46. https://doi.org/10.1177/0027432119895304

Antinluoma, M., Ilomäki, L., Lahti-Nuuttila, P., \& Toom, A. (2018). Schools as professional learning communities. Journal of education and learning 7(5). https://doi.org/10.5539/jel.v7n5p76

Bačlija Sušić, B., \& Svalina, V. (2018). Competences of Educators and Teachers to Recognize and Develop Musical Talent. In Herzog, J. (Eds.) Challenges of Working with Gifted Pupils in European School Systems (p.25-43). Verlag Dr. Kovač.

Billroth, T. (2017). Wer ist musikalisch? [Who is musical?]. Hansebooks.

Bogunović, B. (2008). Muzički talenat i uspešnost [Musical talent and success]. Institut za pedagoška istraživanja.

Brajčić, M., Kuščević, D., \& Lažeta, M. (2020). A Comparison between competencies of teachers and students of teacher education in recognizing artistically gifted students. European Journal of Educational Research, 9(3), 1327 - 1336. https://doi.org/10.12973/eu-jer.9.3.1327

Burnard, P., \& Murphy, R. (2017). Teaching music creatively. Taylor \& Francis.

Clarke, E. F. (2007). The impact of recording on listening. Twentieth-Century Music, 4(01), $47-$ 70. https://doi.org/10.1017/s1478572207000527

Cohen, L., Manion, L., \& Morrison, K. (2000). Research methods in education (5th ed.). Routledge.

Cvetković-Lay, J. (2006). Attitudes towards children with high abilities in EU countries: The reality of Croatian aspirations. In M. Žebec, M. S. Sabol, \& M. Šakić (Eds.) Brain and mind: A permanent challenge to man (pp. 233-246). Institut društvenih znanosti 'Ivo Pilar'.

Cvetković Lay, J., \& Sekulić Majurec, A. (2008). Darovito je, što ću s njim?: Priručnik za odgoj $i$ obrazovanje darovite djece predškolske dobi [He is gifted what can I do with him?: A handbook for education of pre-school gifted children]. Alinea.

Čudina-Obradović, M., \& Posavec, T. (2009). Correlation between positive, negative and ambivalent attitudes of teachers towards giftedness. Napredak: časopis za pedagogijsku teoriju i praksu, $150(3-4), 425-450$.

Davis, G. A., Rimm, S. B., \& Siegle, D. (2014). Leadership, affective learning, and character education. In G. A. Davis, Rimm, S. B., \& Siegle, D. (Eds.), Education of the gifted and talented (pp. 273290). Pearson Education.

Duh, M., \& Lep, K. (2008). Evaluation of artistically gifted pupils in primary school. Journal of Elementary Education, 1(3-4), 95-105.

Elliott, D. J. (Ed.). (2009). Praxial music education: Reflections and dialogues. Oxford University Press. Endepohls-Ulpe, M. (2004). Wie stellen Grundschullehrkräfte sich hochbegabte Schüler/innen vor? Der Einfluss persönlicher Erfahrung in der Unterrichtung Hochbegabter [Primary school teachers' images of a gifted pupil - Effects of personal experience in teaching gifted children]. Psychologie in Erziehung und Unterricht, 51(2), 126-135.

Erwin, J. O., \& Worrell, F. C. (2012). Assessment practices and the underrepresentation of minority students in gifted and talented education. Journal of Psychoeducational Assessment, 30(1), 74-87. https://doi.org/10.1177/0734282911428197

Gagné, F. (1985). Giftedness and talent: Re-examining and re-examination of the definitions. Gifted Child Quarterly, 29(3), 103-112. https://doi.org/10.1177/001698628502900302 
Gagné, F. (1999). My convictions about the nature of abilities, gifts, and talents. Journal for the Education of the Gifted, 22(2), 109-136. https://doi.org/10.1177/016235329902200202

Gagné, F. (2000). Understanding the complex choreography of talent development through DMGT-based analysis. International Handbook of Giftedness and Talent, 2, 67-79. https://doi.org/10.1016/B978-008043796-5/50005-X

Gagné, F. (2004). Transforming gifts into talents: the DMGT as a developmental theory. High Ability Studies, 15(2), 119-147. https://doi.org/10.1080/1359813042000314682

Gardner, H. (1983). Frames of mind: the theory of multiple intelligences. Basic Books.

George, D. (2004). The challenge of the gifted child. David Fulton Publishers.

Gojkov, G. \& Stojanović, A. (Eds.) (2014). Kompetencije učitelja za identifikaciju i rad sa darovitim učenicima [Teacher competencies for identifying and working with gifted students]. Viska škola Mihailo Palov, Vršac.

Gordon, E. E. (1986). Intermediate measures of music audiation. GIA Publications.

Gordon, E. E. (2003). A Music Learning Theory for Newborn and Young Children. GIA Publications.

Hany, E. A. (1991). Identifikation hochbegabter Schüler [Identification of gifted students]. In K. A. Heller (Ed.), Formen der Hochbegabung im Kindes- und Jugendalter [Forms of giftedness in children and adolescents] (pp. 39-200). Hogrefe.

Hargrove, K. (2009). From the classroom: The case of Callie. Gifted Child Today, 32(1), 32-33. https://doi.org/10.4219/gct-2009-844

Haroutounian, J. (2002). Kindling the spark: Recognizing and developing musical talent. Oxford University Press.

Jeremić, B., \& Milenović, Ž. (2017). Uloga vaspitača i učitelja u prepoznavanju i pedagoškoj podršci darovitoj deci [The role of preschool and school teachers in recognizing and giving the pedagogical support to the gifted children]. In M. Šćepanović (Ed.) Darovitost - tematski zbornik radova međunarodnog značaja [Giftedness - international thematic collection of papers] (pp. 146-157). Mensa Serbia.

Koren, I. (1996). Neke karakteristike stavova učitelja o pojavi nadarenosti i nadarenim pojedincima [Some characteristics of teachers' attitudes about the emergence of giftedness and gifted individuals]. Napredak, 137(1), 16-27.

Lelea. J. (2014). Opažanje i poučavanje muzički darovitih učenika u razrednoj nastavi [Observing and teaching musically gifted students in the classroom]. In G. Gojkov \& A. Stojanović (Eds), Kompetencije učitelja za identifikaciju $i$ rad sa darovitim učenicima [Teacher competencies for identifying and working with gifted students] (pp. 55-64). Visoka škola strukovnih studija za vaspitače „Mihailo Palov”.

Lassig, C. J. (2009). Teachers' attitudes towards the gifted: The importance of professional development and school culture. Australasian Journal of Gifted Education, 18(2), 32-42. https://eprints.qut.edu.au/32480/

Marsh, K. (2008). The musical playground: Global tradition and change in children's songs and games. Oxford University Press.

McClain, M. C., \& Pfeiffer, S. (2012). Identification of gifted students in the United States today: A look at state definitions, policies, and practices. Journal of Applied School Psychology, 28(1), 59-88. https://doi.org/10.1080/15377903.2012.643757

Milenović, Ž., \& Lučin, I. (2011). Svojstva učitelja za vaspitanje i obrazovanje učenika sa iznadprosečnim sposobnostima $\mathrm{u}$ inkluzivnoj nastavi [Characteristics of teachers for the education of students with above-average abilities in inclusive teaching]. In T. Varjú Potrebić, \& J. Lepeš (Eds.), $U$ službi talenta (pp. 203-213). Regionalni centar za profesionalni razvoj zaposlenih u obrazovanju u Kanjiži.

Ministarstvo znanosti, obrazovanja i športa (2005). Pravilnik o napredovanju učitelja, nastavnika, stručnih suradnika i ravnatelja u osnovnim i srednjim školama i učeničkim domovima [Ordinance on Promotion of Teachers in Primary and Secondary Schools] (OG 20/05).

Ministarstvo znanosti, obrazovanja i športa (2006). Nastavni plan i program za osnovnu školu [Primary School Curriculum].

Ministarstvo znanosti i obrazovanja Republike Hrvatske (2011). Zakon o umjetničkom obrazovanju [Art Education Act]. https://www.zakon.hr/z/516/Zakon-o-umjetni\%C4\%8Dkom-obrazovanju 
Vesna SVALINA, Blaženka BAČLIJA SUŠIĆ, Goran LAPAT. Primary school teachers' opinions towards musically gifted students

PROBLEMS

OF EDUCATION

IN THE $21^{\text {st }}$ CENTURY Vol. 79 , No. 1, 2021

156

Ministarstvo znanosti i obrazovanja (2019). Kurikulum nastavnih predmeta Glazbena kultura i Glazbena umjetnost za osnovne škole i gimnazije [Curriculum of Music Culture and Music Arts for Primary Schools and Gymnasiums].

Montgomery, D. (2015). Teaching gifted children with special educational needs: Supporting dual and multiple exceptionality. Routledge.

Moon, S. M., \& Rosselli, H. C. (2000). Developing gifted programs. In K. A. Heller, F. J. Mönks, \& R. F. Subotnik (Eds.), International Handbook of Giftedness and Talent (pp. 499-521). Elsevier Science.

Neihart, M., Reis, S. M., Robinson, N., \& Moon, S. (2002). The social and emotional development of gifted children: What do we know? Sourcebooks.

Nikčević-Milković, A., Jerković, A., \& Rukavina, M. (2016). Stanje, problemi i potrebe rada s darovitim učenicima u osnovnim školama u Republici Hrvatskoj [Status, problems and needs working with talented pupils in primary schools in Croatia]. Magistra Iadertina, 11(1), 9-34. https://hrcak.srce. hr/index.php?id clanak jezik=261827\&show=clanak

Nikčević-Milković, A., Jurković, D., \& Perković, L. (2019). Teachers from Lika and Senj County attitudes towards working with pupils with special needs. Školski vjesnik, 68(2), 330-351. https://hrcak. srce.hr/index.php?show=clanak\&id_clanak_jezik $=341498$

Opić, S. (2010). Korištenje neparametrijskih testova u istraživanjima odgoja i obrazovanja [Using NonParametric Tests in Education Research]. In A. Jurčević Lozančić (Ed.) 11. dani Mate Demarina - Očekivanja, postignuća i perspektive u teoriji i praksi ranog i primarnog odgoja i obrazovanja (pp. 307-317). Učiteljski fakultet Sveučilišta u Zagrebu.

Petz, B. (2007). Osnovne statističke metode za nematematičare [Basic statistical methods for nonmathematicians]. Naklada Slap.-

Plucker, J. A., \& Callahan, C. M. (2014). Research on giftedness and gifted education: Status of the field and considerations for the future. Exceptional Children, 80(4), 390-406. https://doi.org/10.1177/0014402914527244

Podolsky, A., Kini, T., \& Darling-Hammond, L. (2019). Does teaching experience increase teacher effectiveness? A review of US research. Journal of Professional Capital and Community, 4(4), 286-308. https://doi.org/10.1108/JPCC-12-2018-0032

Posavec, T. (2008). Stavovi učitelja prema darovitosti $i$ darovitim učenicima u Varaždinskoj županiji [Teachers' attitudes towards giftedness and gifted students in Varaždin County] (Unpublished master's thesis). Učiteljski fakultet Sveučilišta u Zagrebu.

Radičević, A., Sicherl-Kafol, B., \& Juriševič, M. (2013). Motiviranost učiteljev za poučevanje glasbeno nadarjenih učencev [Motivation of teachers to teach musically gifted students]. In M. Juriševič (Ed.), Spodbujanje nadarjenih učencev na umetnostnih področjih: zbornik povzetkov (p. 28). Pedagoška fakulteta v Ljubljani.

Reis, S. M., \& Renzulli, J. S. (2004). Current Research on the Social and Emotional Development of Gifted and Talented Students: Good News and Future Possibilities. Psychology in the Schools, 41(1), 119-130. https://doi.org/10.1002/pits.10144

Renzulli, J. S. (1978). What makes giftedness? Re-examining a definition. Phi Delta Kappan, 60(3), 180. https://doi.org/10.1177/003172171109200821

Renzulli, J. S. (Ed.). (1986). Systems and models for developing programs for the gifted and talented. Creative Learning Press.

Renzulli, J. S. (2002). Emerging conceptions of giftedness: Building a bridge to the new century. Exceptionality, 10(2), 67-75. https://doi.org/10.1207/S15327035EX1002_2

Robinson, W., \& Campbell, J. (2010). Effective teaching in gifted education: Using a whole school approach. Routledge.

Rost, D. H., \& Hanses, P. (1997). Wer nichts leistet, ist nicht begabt? Zur Identifikation hochbegabter Underachiever durch Lehrkräfte [Not achieving - Not gifted? About the identification of gifted children by teacher-ratings]. Zeitschrift für Entwicklungspsychologie und Pädagogische Psychologie, 29(2), 167-177.

Schroth, S. T., \& Helfer, J. A. (2020). Educator Perceptions of Artistically Gifted Children: Degree of Alignment between Beliefs of Music Specialists, Art Specialists, and Administrators. Educational Research Quarterly, 43(3), 52-83.

Seashore, C. E. (1919). The psychology of musical talent. Silver, Burdett. 
Schroth, S. T., \& Helfer, J. A. (2020). Educator Perceptions of Artistically Gifted Children: Degree of Alignment between Beliefs of Music Specialists, Art Specialists, and Administrators. Educational Research Quarterly, 43(3), 52-84.

Sternberg, R. J. (2003). WICS as a model of giftedness. High Ability Studies, 14(2), 109-137. https://doi.org/10.1080/1359813032000163807

Sternberg, R. J. (2007). Cultural concepts of giftedness. Roeper Review, 29(3), 160-165. https://doi.org/10.1080/02783190709554404

Sternberg, R. J. (2012). Giftedness and ethics. Gifted Education International, 28(3), 241-251. https://doi.org/10.1177/0261429411435050

Sukop, I., Metić, M., \& Svalina, V. (2016). Odgoj i obrazovanje glazbeno darovitih učenika iz perspektive učitelja primarnoga obrazovanja. In S. Zrilić (Ed.) Suvremeni pristup odgoju i obrazovanju darovite djece i učenika, zbornik radova (p. 281-297). Sveučilište u Zadru; Odjel za izobrazbu učitelja i odgojitelja.

Sutherland, M. (2015). Nadarjeni v zgodnjem otroštvu. Dejavnosti za otroke, stare od 3 do 6 let. [Gifted in early childhood. Activities for children from 3 to 6 years]. Pedagoška fakulteta v Ljubljani.

Suzić, N. (2007). Primijenjena pedagoška metodologija [Applied Pedagogical Methodology]. XBS.

Svalina, V. (2015). Kurikulum nastave glazbene kulture i kompetencije učitelja za poučavanje glazbe [Music curriculum and teachers' competences for music teaching]. Sveučilište Josipa Jurja Strossmayera u Osijeku, Fakultet za odgojne i obrazovne znanosti.

Svalina, V. \& Matijević, M. (2011). Glazbeno daroviti učenici na primarnom stupnju školovanja [Musically gifted students at primary level of education]. Napredak, 152(3-4), 425-445. https://hrcak.srce.hr/index.php?show=clanak\&id_clanak_jezik=123175

Tannenbaum, A. J. (2000). Giftedness: The Ultimate Instrument for Good and. In K. A. Heller, F. J. Mönks, R. Subotnik, \& Robert J. Sternberg (Eds.) International Handbook of Giftedness and Talent (pp. 447-465). Elsevier Science.

Tomlinson, C. A., Tomchin, E. M., Callahan, C. M., Adams, C. M., Pizzat-Tinnin, P., Cunningham, C. M., Moore, B., Lutz, L. Roberson, C., Eiss, N., Landrum, M., Hunsaker, S., \& Imbeau, M. (2004). Practices of preservice teachers related to gifted and other academically diverse learners. In C. A. Tomlinson, \& S. M. Reis (Eds.) Differentiation for Gifted and Talented Students (pp. 191- 208). Corwin Press.

White, K., Fletcher-Campbell, F., \& Ridley, K. (2003). What works for gifted and talented pupils: A review of recent research. National Foundation for Educational Research.

Wiggins, J. (2007). Compositional process in music. In L. Bresler (Ed.), International handbook of research in arts education (pp. 453-476). Springer.

Winner, E., \& Martino, G. (2000). Giftedness in non-academic domains: The case of the visual arts and music. In K. A. Heller, F. J. Monks, R. J. Sternberg, \& R. F. Subotnik (Eds.), International handbook of giftedness and talent (2nd ed., pp. 95-110). Elsevier.

Zalar, K., \& Sicherl Kafol, B. (2015). Nadarjeni učenci pri celostnem pouku glasbene umetnosti [Gifted students in integrated music lessons]. In T. Devjak (Ed.), Vpliv družbenih sprememb na vzgojo in izobraževanje [The impact of social change on education] (pp. 369- 382). Pedagoška fakulteta Ljubljana.

\section{Attachment}

\section{Questionnaire}

Dear teacher,

This questionnaire is a part of bilateral project "Giftedness in the artistic field - analysis of the situation among primary school students in terms of artistic and musical giftedness" carried out by experts from the Faculty of Education, University of Maribor and the Faculty of Teacher Education, University of Zagreb. Project is financed by the Ministry of Science and Education of the Republic of Croatia and the Research Agency of the Republic of Slovenia. 
Vesna SVALINA, Blaženka BAČLIJA SUŠIĆ, Goran LAPAT. Primary school teachers' opinions towards musically gifted students

PROBLEMS

OF EDUCATION

IN THE $21^{\text {st }}$ CENTURY

Vol. 79 , No. 1,202

158

We are kindly asking you to honestly fill the questionnaire, because it grants us the quality of the obtained data, and thereby the relevance of the results. The anonymity of the questionnaire is guaranteed.

Thank you!

\section{Gender}

- Female

- Male

2. Years of service:

\section{What is your vocation?}

- Teacher

- Teacher mentor

- Teacher advisor

4. What is your age?

- 30 and under

- $31-40$

- $41-50$

- 51 and over

5. Circle the county where the school where you teach is located.

Bjelovar-Bilogora County

- Brod-Posavina County

- Dubrovnik-Neretva County

- Istria County

- Karlovac County

- Koprivnica-Križevci County

- Krapina-Zagorje County

- Kvarner County

- Lika-Senj County

- Međimurje County

- Osijek-Baranja County

- Požega-Slavonija County

- Sisak-Moslavina County

- Split-Dalmatia County

- Šibenik-Knin County

- Varaždin County

- Virovitica-Podravina County

- Vukovar-Srijem County

- Zadar County

- Zagreb City

- Zagreb County 
6. What kind of the environment is around your school?

- Urban

- Rural

7. Write the number of students in the previous school year!

How many of these were musically gifted?

8. State how you recognize / evaluate a musically gifted child.

9.

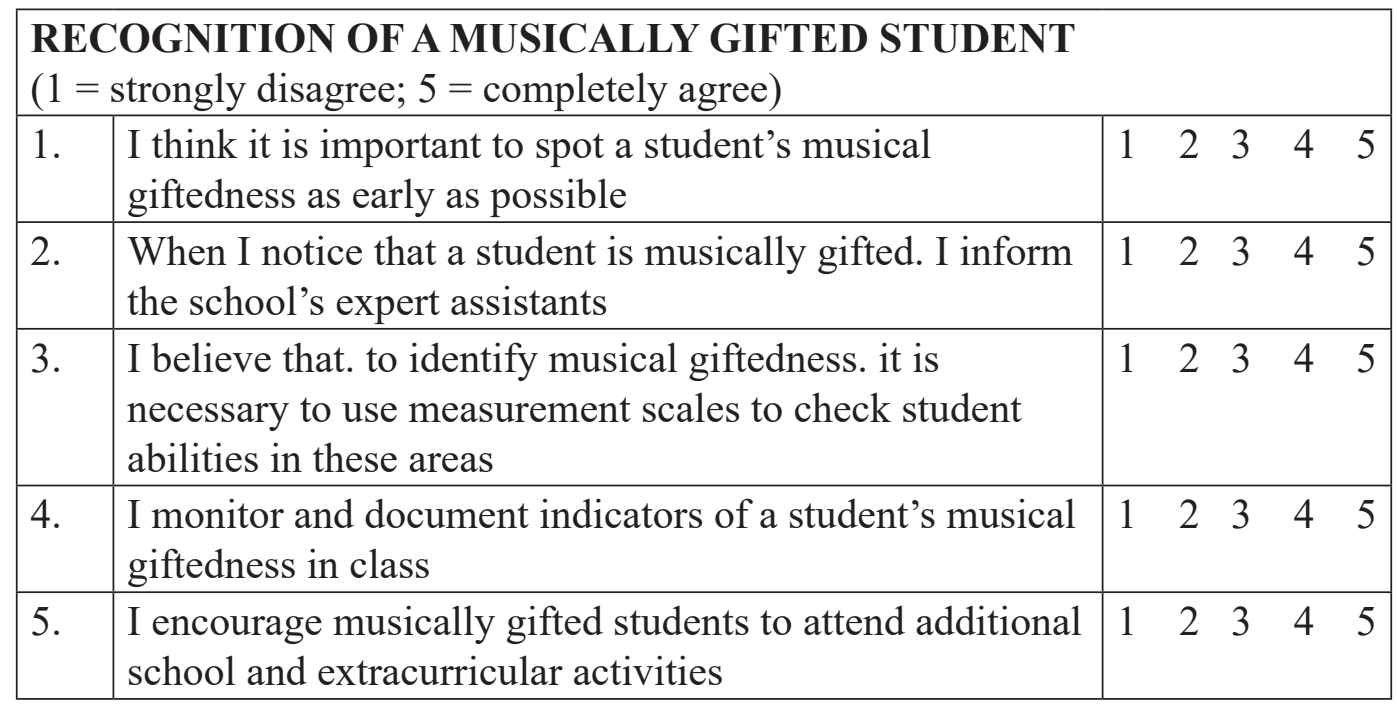


PROBLEMS

OF EDUCATION IN THE $21^{\text {st }}$ CENTURY Vol. 79, No. 1, 2021

160
10.

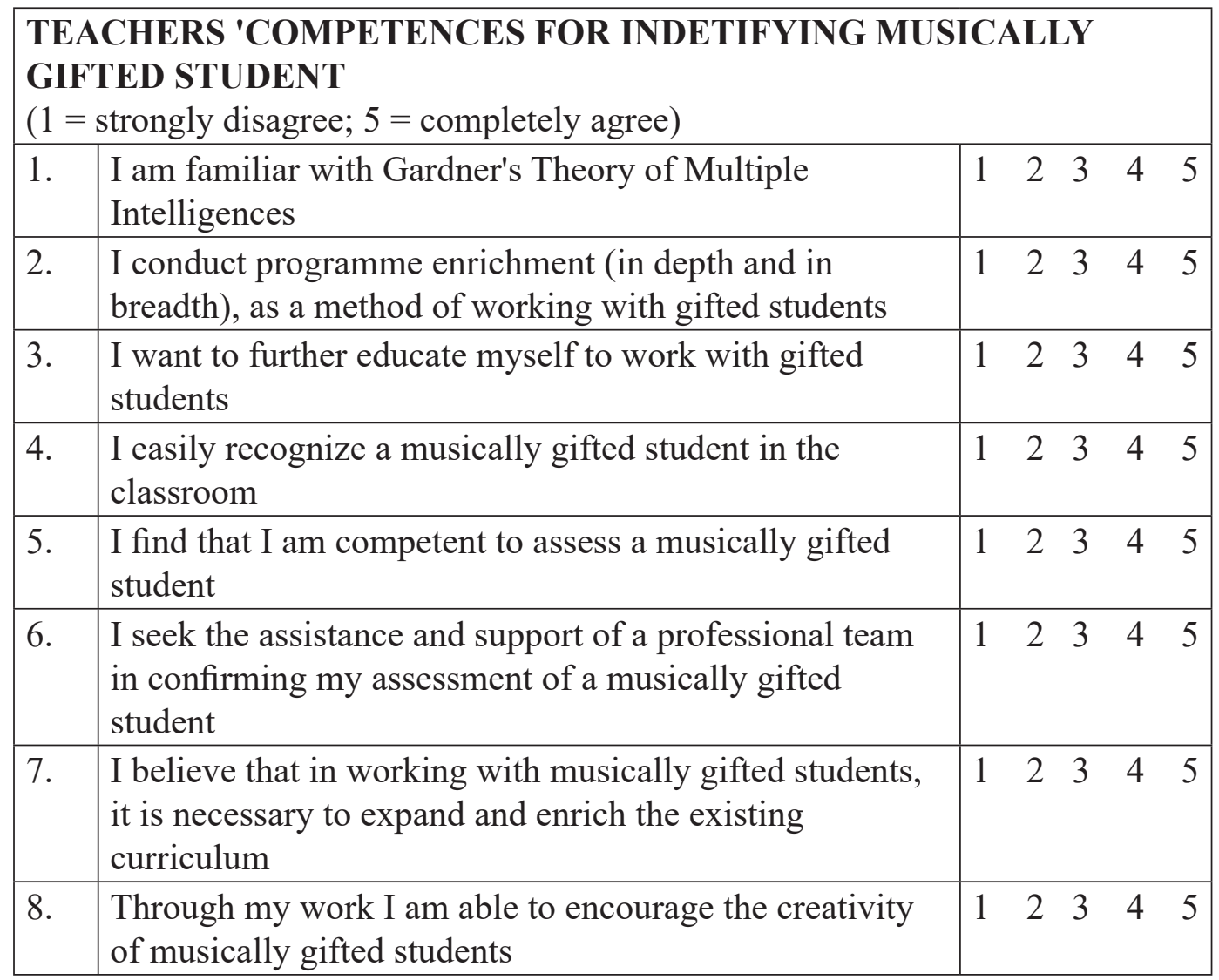

11.

\section{CONDITIONS FOR THE ENCOURAGEMENT AND DEVELOPMENT OF MUSICALLY GIFTED STUDENT $(1$ = strongly disagree; $5=$ completely} agree)

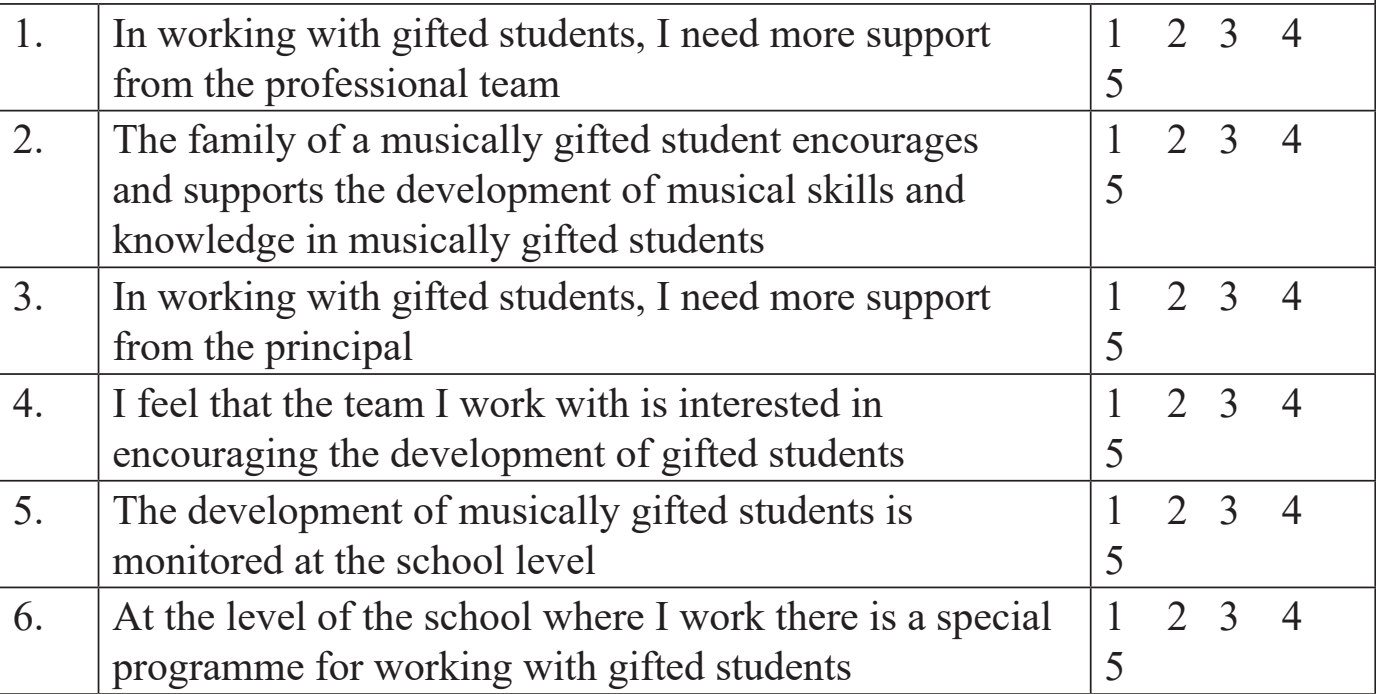


Vesna SVALINA, Blaženka BAČLIJA SUŠIĆ, Goran LAPAT. Primary school teachers' opinions towards musically gifted students

PROBLEMS

OF EDUCATION

IN THE $21^{\text {st }}$ CENTURY

Vol. 79, No. 1, 2021

161

Received: September 09, 2020

Accepted: January 26, 2021

Cite as: Svalina, V., Bačlija Sušič, B., \& Lapat, G. (2021). Primary school teachers`opinions towards musically gifted students. Problems of Education in the $21^{\text {st }}$ Century, 79(1), 133-161. https://doi.org/10.33225/pec/21.79.133

\section{Vesna Svalina}

(Corresponding author)
PhD, Assistant Professor, Head of Music Subdepartment at the Faculty of Teacher Education, University of Josip Juraj Strossmayer in Osijek, Ulica Cara Hadrijana 10, 31000 Osijek, Croatia.

E-mail: vesna.svalina@gmail.com

Website: https://www.vesna-svalina.net/

ORCID: http://orcid.org/0000-0002-1998-739X

Blaženka Bačlija Sušić

$\mathrm{PhD}$, Assistant Professor, Faculty of Teacher Education, University of Zagreb, Savska cesta 77, 10000 Zagreb, Croatia.

E-mail: blazenkabs@gmail.com

Website: https://www.ufzg.unizg.hr/zaposlenici/baclija-susic-blazenka/ ORCID: https://orcid.org/0000-0002-0984-765X

Goran Lapat

PhD, Assistant Professor, Faculty of Teacher Education, University of Zagreb, Savska cesta 77, 10000 Zagreb, Croatia.

E-mail: goran.lapat@ufzg.hr

Website: https://www.ufzg.unizg.hr/zaposlenici/lapat-goran/

ORCID: https://orcid.org/0000-0002-7548-3145 